\title{
Especiación de metales pesados en la fracción disuelta de las aguas superficiales de la cuenca baja y la pluma del Río Manzanares, Estado Sucre, Venezuela
}

\author{
Heavy metal speciation in the surface water dissolved fraction of the low watershed and plume \\ of the Manzanares River, Sucre State, Venezuela
}

\author{
G Martínez*, W Senior**, A Márquez
}

\begin{abstract}
Departamento de Oceanografía - Instituto Oceanográfico de Venezuela, Universidad de Oriente, Núcleo de Sucre, Avenida Universidad, Cerro Colorado. Apartado Postal 245, 6101 Cumaná, Estado Sucre, Venezuela.

E-mail:* gmartine@sucre.udo.edu.ve,** wsenior@sucre.udo.edu.ve.
\end{abstract}

\section{Resumen}

Se estudió la especiación de los metales pesados $\mathrm{Fe}, \mathrm{Mn}, \mathrm{Ni}, \mathrm{Cr}, \mathrm{Cu}, \mathrm{Cd}, \mathrm{Pb}$ y Zn en la fracción disuelta en las aguas superficiales de la cuenca baja y pluma del Río Manzanares, Estado Sucre, Venezuela, durante el periodo comprendido entre julio de 1996 y junio de 1997, en 22 estaciones establecidas en la cuenca baja y pluma de dicho río. Las concentraciones totales

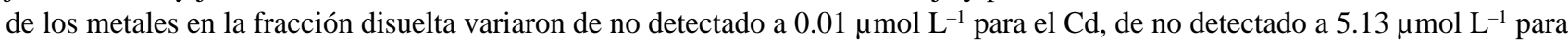

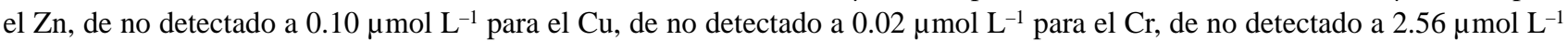
para el Fe, de no detectado a $1.03 \mu \mathrm{mol} \mathrm{L}{ }^{-1}$ para el Mn, de no detectado a $0.10 \mu \mathrm{mol} \mathrm{L}{ }^{-1}$ para el Ni y de no detectado a $0.02 \mu \mathrm{mol}$ $\mathrm{L}^{-1}$ para el $\mathrm{Pb}$. En general, los metales evaluados presentaron un comportamiento no conservativo con remoción a bajas salinidades posiblemente debida a la floculación al formarse oxihidróxidos de Fe y Mn como consecuencia de los cambios de pH y fuerza iónica que ocurren cuando se mezclan las aguas dulces del río con las marinas del Golfo de Cariaco, además de observarse aportes de estos elementos a todo lo largo de la pluma debido a las actividades humanas que se desarrollan en la zona. De igual manera, los metales pesados en la fracción disuelta presentan una composición en la que las mayores proporciones se encuentran asociadas a los ácidos húmicos (extraídos con la resina DEAE) y en forma libre e hidratada (extraídos con la resina Chelex-100), las cuales son las especies más disponibles para los organismos vivos..

Palabras clave: especiación de metales pesados, Río Manzanares, fracción disuelta.

\begin{abstract}
This paper reports on the speciation of heavy metals (Cd, Pb, Cr, $\mathrm{Cu}, \mathrm{Ni}, \mathrm{Mn}, \mathrm{Fe}$, and $\mathrm{Zn}$ ) in the surface water dissolved fraction of the low basin and plume of the Manzanares River, in the state of Sucre, Venezuela, based on data taken at 22 stations from July 1996 to June 1997. The total metal concentrations in the dissolved phase ranged from below detection levels to 0.01, 0.02, 0.02, 0.10, 0.10, 1.03, 2.56, and $5.13 \mu \mathrm{mol} \mathrm{L} \mathrm{L}^{-1}$ for $\mathrm{Cd}, \mathrm{Pb}, \mathrm{Cr}, \mathrm{Cu}, \mathrm{Ni}, \mathrm{Mn}, \mathrm{Fe}$, and $\mathrm{Zn}$, respectively. Overall, the metals studied revealed a nonconservative behavior with removal at low salinities, likely due to anthropogenic contributions and to flocculation on account of Fe- and Mn-oxyhydroxide formation resulting from the shifts in $\mathrm{pH}$ and ion forces that ensue when the fresh waters of the river meet the marine water mass of the Gulf of Cariaco. The heavy metals in the dissolved fraction, in both free and hydrated form, had a composition in which the largest proportions were associated with humic acids, thus being more readily available to organisms.
\end{abstract}

Key words: heavy metal speciation, Manzanares River, dissolved fraction.

\section{Introducción}

Los ríos son el principal vehículo de transporte de constituyentes químicos hacia el medio marino, especialmente de metales pesados (Zhang et al. 1992, Yeats 1993). Se ha reconocido que las descargas de los ríos influyen en la variabilidad espacial y temporal de los metales pesados (Gibbs 1977, Palanques 1994). Por otra parte, los ríos contribuyen aportes significativos de materia orgánica e inorgánica, rica en metales trazas que son liberados durante el proceso de degradación orgánica (Magnusson y Rasmussen 1982, Valette-Silver 1993).

En las últimas dos décadas se ha producido un gran cambio en la comprensión de la biogeoquímica de los metales pesados

\section{Introduction}

Rivers are the main pathway for the transport of chemical constituents, especially heavy metals, to the sea (Zhang et al. 1992, Yeats 1993). It has been determined that river discharges influence the spatial and temporal variability of heavy metals in coastal marine ecosystems (Gibbs 1997, Palanques 1994). Furthermore, rivers contribute significant inputs of organic and inorganic matter rich in trace metals that are released during organic breakdown (Magnusson and Rasmussen 1982, ValetteSilver 1993).

The understanding of the biogeochemistry of heavy metals in marine environments has changed considerably during the 
en los sistemas marinos. Un entendimiento más detallado acerca del ciclo de los metales pesados en el medio ambiente podría, no obstante, requerir información sobre la especiación química de los metales en solución, es decir, sobre las formas fisicoquímicas específicas que forman parte de la concentración total de un elemento en solución. La especiación de los metales pesados en solución está controlada en gran parte por el intercambio entre la fase acuosa-sólida, las reacciones redox y por la serie de ligandos disponibles para la formación de complejos (Stumm y Morgan 1981, Andreae 1986). Por otra parte, la especiación de los metales gobierna las interacciones con el material en suspensión y los sedimentos, determina la biodisponibilidad y/o toxicidad de los metales para los organismos acuáticos, además de tener influencia en el ciclo de los metales a través de los estuarios al igual que en la interfase agua-sedimento en ambientes con diferentes condiciones redox.

El Río Manzanares constituye un cuerpo de agua de vital importancia para la región suroccidental del Estado Sucre y en especial para los centros poblados ubicados en sus márgenes en las que se realizan diferentes actividades agropecuarias, industriales, de esparcimiento y, de igual manera, aprovechan sus aguas para las labores domésticas. En los últimos años estas actividades se han visto incrementadas considerablemente. Su cauce recibe las aguas residuales de todas esas actividades, sin ningún tratamiento y con poco control por las autoridades competentes. En los últimos años se ha puesto atención en el comportamiento de los metales pesados en este río, reportándose concentraciones totales de $\mathrm{Cd}$ y $\mathrm{Pb}$ moderadamente altas, de origen antropogénico, que pueden afectar a los organismos que se desarrollan en este ecosistema, y se ha establecido una relación directa entre la concentración de los metales pesados, el volumen de agua descargado por el río y su material en suspensión (León et al. 1997). Por otra parte, Márquez et al. (2000, 2002) estudiaron la distribución de algunos metales pesados en las aguas del Manzanares, concluyendo que en él los metales en su mayoría se encuentran contenidos en el material en suspensión e igualmente asociados al gasto del río. De igual manera, Martínez y Senior (2001) observaron, durante el período de lluvia, concentraciones elevadas de $\mathrm{Cd}, \mathrm{Cu}$ y $\mathrm{Zn}$ en el material en suspensión en forma de carbonatos y/o oxihidróxido de Mn, y que el Cr está asociado principalmente a los minerales de arcilla, lo cual revela que la concentración de los metales del primer grupo puede tener su origen en las actividades antrópicas que se desarrollan en la región que conforma la cuenca baja del río y su desembocadura. El presente trabajo estudia la distribución, especiación y variabilidad espaciotemporal de los metales pesados (Cd, Cu, Ni, Zn, Fe, Mn, Cr y $\mathrm{Pb}$ ) en la fracción disuelta de las aguas superficiales en la cuenca baja y pluma del Río Manzanares.

\section{Area de estudio}

La cuenca baja del Río Manzanares está ubicada en el Estado Sucre, Venezuela (fig. 1). Su nacimiento está situado a last two decades. A more thorough comprehension of heavy metal cycling in the environment could, however, require information on the chemical speciation of metals in solution; that is, the specific physicochemical forms that are part of the total concentration of an element in solution. The speciation of heavy metals in solution is mediated to a great extent by the exchange between the aqueous and solid phases, the redox reactions, and a series of ligands available for complex formation (Stumm and Morgan 1981, Andreae 1986). On the other hand, metal speciation controls the interactions between the matter in suspension and the sediments, and determines the bioavailability and/or toxicity of the metals for aquatic organisms, in addition to affecting the cycle of metals in estuarine environments and in the water-sediment interface of different redox milieu.

The Manzanares River is a body of water of vital importance to the southwestern region of the state of Sucre (Venezuela) and especially to the towns where farming, industrial and recreational activities are conducted along its banks, as well as to the people who avail themselves of its waters for domestic use, a practice that has increased considerably during the last few years. Residual waters from these activities find their way to the river with no treatment and little control, reason why much attention has been focused on the behavior of heavy metals in this waterway.

A direct relation between heavy metal concentration, the volume of water discharged by the river and its suspended matter has been established (León et al. 1997), the total concentrations of $\mathrm{Cd}$ and $\mathrm{Pb}$, of anthropogenic origin, being moderately high and constituting a potential hazard to organisms. Márquez et al. (2000, 2002) studied the distribution of some heavy metals in the river water and concluded that most metals are contained in the suspended matter and associated with the river output. During the rainy season, Martínez and Senior (2001) observed high concentrations of $\mathrm{Cd}, \mathrm{Cu}$, and $\mathrm{Zn}$ in the form of carbonates and/or Mn-oxyhydroxides. They also noticed that Cr was mainly associated with clayey minerals and reported that the first group of metals could have its origin in the anthropogenic activities carried out in the region, comprising the low river watershed and the mouth of the river. This paper addresses the distribution, speciation, and space-time variability of heavy metals $(\mathrm{Cd}, \mathrm{Cr}, \mathrm{Pb}, \mathrm{Cu}, \mathrm{Ni}, \mathrm{Mn}, \mathrm{Fe}$, and $\mathrm{Zn}$ ) in the dissolved fraction of the watershed and plume of the Manzanares River.

\section{Study area}

The low basin of the Manzanares River is located in northeastern Venezuela, in the state of Sucre (fig. 1). It springs from the Turimiquire massif $2300 \mathrm{~m}$ above sea level and empties into the entrance to the Gulf of Cariaco. Along its course it receives the discharges of more than ten tributaries, the Guasdua River contributing the largest volume of domestic and industrial contaminants, especially those from a sugar cane processing plant and the effluents of the domestic enclaves in 
2300 metros sobre el nivel del mar en el macizo del Turimiquire y desemboca en la entrada del Golfo de Cariaco. Este río recibe las descargas de más de diez afluentes, entre los que el Río Guasdua aporta la mayor cantidad de contaminantes domésticos e industriales provenientes de los desechos de la central azucarera de Cumanacoa y los efluentes domésticos de los centros poblados de la región (Senior y Godoy 1990). Las descargas del Río Manzanares dan origen a una pluma laminar cuyos límites forman un sistema semejante a un frente. La pluma se dirige, generalmente, hacia el Sur-Oeste como consecuencia de los vientos alisios. Durante la temporada anual de lluvia, la descarga del río se hace mayor y su pluma puede llegar hasta la región de Puerto Escondido y la Bahía de Mochima (León et al. 1997). En la margen costera cerca de su desembocadura se encuentran ubicados algunos astilleros y un varadero para la construcción y mantenimiento de embarcaciones, así como el puerto que aloja la flota pesquera establecida en Cumaná. Debido a ello, cada cierto tiempo se realizan dragados a la entrada de los puertos y astilleros de la zona, los cuales resuspenden gran cantidad de sedimentos que afectan la calidad de las aguas y la dinámica sedimentaria de este ecosistema. La región ha sido estudiada por Senior y Godoy (1990), León et al. (1997), Márquez et al. (2000), y Martínez y Senior (2001), dentro del marco del Programa de Estudio Ambiental del Río Manzanares llevado a cabo por el Departamento de Oceanografía del Instituto Oceanográfico de Venezuela.

\section{Materiales y métodos}

Se recolectaron muestras de aguas superficiales, de manera bimensual, entre julio de 1996 y junio de 1997 en 22 estaciones, siguiendo el gradiente salino desde 0.00 ups aproximadamente en el Puente Raúl Leoni, sector Las Palomas, hasta alcanzar salinidades superiores a 36.00 ups en su pluma en dirección Sur-Norte (fig. 1). Las salinidades in situ fueron estimadas utilizando un salinómetro portátil YSI modelo 33 y luego corregidas en el laboratorio utilizando un salinómetro de inducción Kahlsico modelo 118WC200 con una precisión 0.001 ups. Las muestras se filtraron a través de filtros de nitrocelulosa Millipore de $0.45 \mu \mathrm{m}$ para recolectar el material en suspensión (MES) en entre 0.50 a $1 \mathrm{~L}$ de muestra de agua, dependiendo de las concentraciones de este material suspendido. Luego, por medio de una bomba peristáltica, se pasaron $350 \mathrm{~mL}$ a través de una secuencia de columnas para el fraccionamiento de los metales disueltos. Esta técnica fue desarrollada y probada por Lewis y Landing (1992) para estudiar la especiación de metales pesados en el Mar Negro, Mar de los Sargazos y el Estuario del Río Ochlockonee. La primera columna contiene $1 \mathrm{~mL}$ de resina Toyopearl HW-75 F (TosoHaas, Philadelphia, PA), la cual es un polímero de vinilo aglomerado, muy utilizado en cromatografía de geles, con un tamaño de grano de 32-63 $\mu \mathrm{m}$ y poros de $7.5 \mathrm{~nm}$ aproximadamente (Landing et al. 1986). Esta resina es hidrofílica y posee gran estabilidad mecánica y química, gran porosidad, no tiene capacidad de intercambio significativa y no libera ni absorbe compuestos

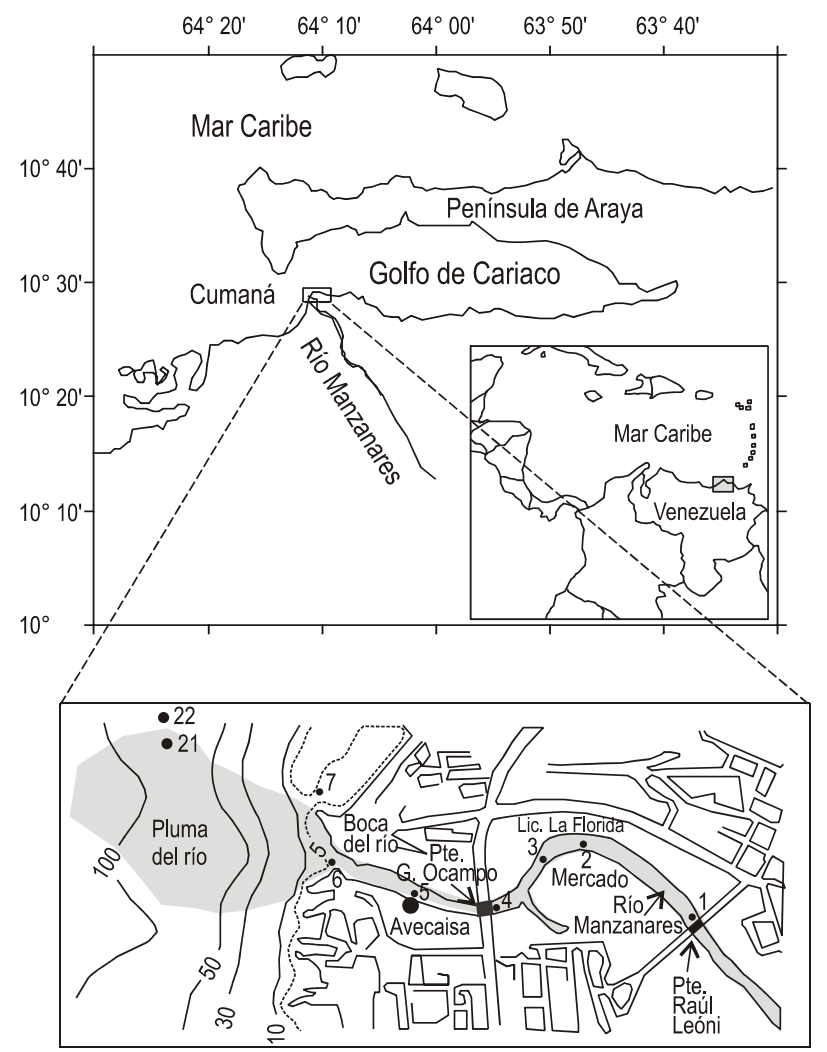

Figura 1. Región de Río Manzanares y su desembocadura donde se llevó a cabo el presente estudio.

Figure 1. Area of the Manzanares River and its mouth where this study took place.

the region (Senior and Godoy 1990). The discharges into the Manzanares River generate a laminar plume whose limits form a system similar to that of a marine front. The plume generally spreads out towards the southwest as a consequence of the trade winds. During the annual rainy season, the river discharge becomes much larger and the river plume may reach coastal zones such as Puerto Escondido and Mochima Bay, some $20 \mathrm{~km}$ from the mouth of the river (León et al. 1997). The coastal area near the river mouth is home to boat manufacturing companies and a shipyard. The adjacent port also harbors the city's fishing fleet, which commands sporadic dredging of the shipping channels, an action that resuspends sediments and affects the quality of the waters and the sedimentation dynamics of the area. This area has been studied by Senior and Godoy (1990), León et al. (1997), Márquez et al. (2000), and Martínez and Senior (2001), in the framewok of the Evironmental Study Program of the Manzanares River conducted by the Oceanography Department of the Oceanographic Institute of Venezuela.

\section{Material and methods}

Between July 1996 and June 1997, bimonthly samples of surface water were collected at 22 stations following the saline 
orgánico; puede atrapar la mayoría de las partículas coloidales rígidas, tales como los coloides de oxihidróxidos metálicos y coloides de sulfuros metálicos, mientras que las especies metal-ligandos orgánicos de alta masa molar pueden ser separados en el paso siguiente. La columna puede actuar como un filtro profundo de "caminos tortuosos", que atrapa eficientemente los coloides rígidos cerca del tope de la columna.

La segunda columna en la serie contiene $1.0 \mathrm{~mL}$ de resina Toyopearl DEAE 650(M) (Tosoltaas), la cual es una resina HW modificada con grupos funcionales dietilaminoetil de intercambio aniónico que atrapa ácidos débiles. Las resinas DEAE han sido usadas para separar sustancias húmicas polianiónicas disueltas en aguas naturales (Miles et al. 1983, Thurman 1985). Landing et al. (1986) demostraron que con la resina DEAE se pueden recolectar complejos metal-ácido fúlvico de las aguas fluviales y salobres.

La columna final en la secuencia contiene $1.0 \mathrm{~mL}$ de resina Chelex-100, una resina de intercambio catiónico constituida por copolímeros de estireno y divinilbenceno, los cuales contienen iones iminodiacetato apareados que pueden actuar como grupos quelantes para iones metálicos polivalentes. Esta resina es altamente selectiva para metales pesados en cantidades trazas pero posee relativamente baja capacidad de enlace para los cationes más abundantes en el agua de mar ( $\mathrm{Na}, \mathrm{Ca}, \mathrm{Mg}$ y K), constituyendo así un excelente ligando para la preconcentración de metales del agua de mar. Dicha resina también es eficiente para extraer metales de aguas fluviales y estuarinas.

En todos los casos, la elución se realizó con una mezcla de $0.50 \mathrm{~mol} \mathrm{~L}^{-1}$ de $\mathrm{HCl}$ y $0.10 \mathrm{~mol} \mathrm{~L}^{-1}$ de $\mathrm{HNO}_{3}$, obteniéndose las fracciones D1 para la resina HW, D2 para la DEAE y D3 para la resina Chelex-100.

Todos los envases y materiales utilizados fueron lavados con solución de ácido nítrico al 5\%. Para la preparación de soluciones y lavado del material de vidrio utilizado se utilizó agua desionizada obtenida en un equipo desionizador Barnstead Nanopure UV (18 M -cm).

Los metales fueron determinados por espectrofotometría de absorción atómica utilizando un equipo Perkin Elmer mod. 3110 con bola de impacto y un corrector de fondo de deuterio. Los límtes de detección fueron determinados mediante la expresión:

$$
\text { Límite de detección }=(\hat{a}+10 * \sigma) / F D
$$

donde â = promedio de las lecturas del blanco, $\sigma=$ desviación estándar del blanco $(n=15)$ y FD = factor de concentración del método.

La precisión de los métodos utilizados en el caso de la fracción disuelta fue comprobada para la resina Chelex-100 debido a que no se pudo preparar un agua con un contenido de materiales coloidales y materia orgánica disuelta similar al del Río Manzanares. Esta técnica fue probada por Lewis y Landing (1992), obteniendo resultados reproducibles. Los valores de la desviación estándar fueron muy bajos, y los porcentajes de gradient, starting at 0.00 psu at the Raul Leoni Bridge in Las Palomas and reaching values in excess of 36.00 psu in the plume in a south-northerly direction (fig. 1). Salinities were estimated in situ using a portable YSI model 33 salinometer, and were then corrected in the laboratory with a Kahlsico 118 WC200 induction salinometer with 0.001 psu precision. The water samples, ranging from 0.5 to $1.0 \mathrm{~L}$ depending on the suspended matter concentration, were filtered through a $0.45-\mu \mathrm{m}$ nitrocellulose mesh to collect the particulate matter. Using a peristaltic pump, a $350-\mathrm{mL}$ sample of the filtrate was passed through a sequence of columns to fraction the dissolved metals. This technique was developed and tested by Lewis and Landing (1992) to study heavy metal speciation in the Black Sea, the Sargasso Sea, and the Ochlockonee River estuary. The first column was packed with $1 \mathrm{~mL}$ of Toyopearl HW-75F resin (TosoHaas, Philadelphia, PA), an agglomerate vinyl polymer with a particle size of 32-63 $\mu \mathrm{m}$ and an approximate pore size of $7.5 \mathrm{~nm}$ (Landing et al. 1986). This resin is hydrophilic and has high mechanical and chemical stability, high porosity, no significant exchange capacity and does not release nor absorb organic compounds; it can trap most of the rigid colloidal particles such as metal oxyhydroxide and metal sulfur colloids, whereas the metal-organic ligand species of high molecular mass can be separated in the following step. The column can act as a deep, winding filter that efficiently traps rigid colloids near the top of the column.

The second column in the series was packed with $1.0 \mathrm{~mL}$ of Toyopearl DEAE 650 (M) (TosoHaas), a modification of the HW resin with functional anion-exchange diethylaminoethyl groups to trap weak acids, used to separate polyanion humic substances dissolved in natural waters (Miles et al. 1983, Thurman 1985). Landing et al. (1986) demonstrated that metal-fulvic acid complexes can be collected with DEAE resins from fluvial and brackish waters.

The final column in the series was packed with $1.0 \mathrm{~mL}$ of Chelex-100, a styrene-divinylbenzene cation-exchange copolymer containing paired iminodiacetate ions acting as chelating groups for polyvalent metallic ions. This resin, highly selective for heavy metals in trace amounts but with a relatively low binding capacity for the most abundant cations in seawater ( $\mathrm{Na}, \mathrm{Ca}, \mathrm{Mg}$, and $\mathrm{K}$ ), has been efficiently used to extract metals from fluvial and estuarine waters.

In all cases, the elution was carried out with a mixture of $0.5 \mathrm{~mol} \mathrm{~L}^{-1} \mathrm{HCl}$ and $0.10 \mathrm{~mol} \mathrm{~L}^{-1} \mathrm{HNO}_{3}$ to obtain fractions D1, D2, and D3, corresponding to the HW, DEAE, and Chelex-100 resins, respectively.

The glassware and materials used were washed with a 5\% nitric acid solution. The water used for preparing solutions and washing glassware was deionized water from a Barnstead Nanopure UV deionizer (18 M $\Omega$ ).

The metals were determined by atomic absorption spectrophotometry using a Perkin Elmer 3110 apparatus fitted with an impact ball and deuterium lamp background 
Tabla 1. Precisión para la recuperación (Rec.) de metales pesados en agua estuarina utilizando la resina de intercambio iónico Chelex-100. La concentración está expresada en $\mathrm{mg} \mathrm{L}^{-1}$ (promedio \pm desviación estándar).

Table 1. Accuracy and precision standards for the recovery (Rec.) of heavy metals in estuarine waters using Chelex-100 ion exchange resin. The concentration is expressed in $\mathrm{mg} \mathrm{L}^{-1}$ (mean \pm standard deviation).

\begin{tabular}{cccccccc}
\hline & $\mathrm{Cd}$ & $\mathrm{Cu}$ & $\mathrm{Ni}$ & $\mathrm{Fe}$ & $\mathrm{Zn}$ & $\mathrm{Mn}$ & $\mathrm{Pb}$ \\
\hline & $0.802 \pm 0.008$ & $0.978 \pm 0.006$ & $0.947 \pm 0.007$ & $0.902 \pm 0.007$ & $0.801 \pm 0.008$ & $0.962 \pm 0.009$ & $0.945 \pm 0.006$ \\
\% Rec. & 80.20 & 97.80 & 94.7 & 90.20 & 80.10 & 96.20 & 94.50 \\
\hline
\end{tabular}

Tabla 2. Reproducibilidad para la determinación de metales a tres salinidades diferentes y a un pH de 4.75, utilizando la resina quelatante Chelex-100. La concentración está expresada en $\mathrm{mg} \mathrm{L}^{-1}$ (promedio \pm desviación estándar).

Table 2. Reproducibility for the determination of metals at three different salinities and a pH of 4.75 , using Chelex-100 chelating resin. The concentration is expressed in $\mathrm{mg} \mathrm{L}^{-1}$ (mean \pm standard deviation).

\begin{tabular}{ccccccccc}
\hline Salinidad & $\mathrm{Cd}$ & $\mathrm{Cu}$ & $\mathrm{Ni}$ & $\mathrm{Fe}$ & $\mathrm{Zn}$ & $\mathrm{Mn}$ & $\mathrm{Pb}$ & $\mathrm{Cr}$ \\
\hline 2.068 & $0.0039 \pm 0.0004$ & $0.0016 \pm 0.0002$ & $0.0069 \pm 0.0016$ & $0.0047 \pm 0.0009$ & $0.0114 \pm 0.0030$ & $<0.0003^{*}$ & $<0.0002^{*}$ & $0.0023 \pm 0.0007$ \\
15.994 & $0.0040 \pm 0.0003$ & $0.0013 \pm 0.0001$ & $0.0065 \pm 0.0009$ & $0.0051 \pm 0.0007$ & $0.0104 \pm 0.0026$ & $<0.0003^{*}$ & $<0.0002^{*}$ & $0.0025 \pm 0.0004$ \\
35.845 & $0.0038 \pm 0.0003$ & $0.0017 \pm 0.0004$ & $0.0064 \pm 0.0007$ & $0.0066 \pm 0.0017$ & $0.0152 \pm 0.0017$ & $0.0009 \pm 0.0001$ & $<0.0002 *$ & $0.0018 \pm 0.0003$ \\
\hline
\end{tabular}

* Lim. cuantificación: $(\hat{a}+10 * \sigma) / F D$, donde â = promedio de lecturas de blancos; $\sigma=$ desv. blancos, con $n=15 ; y$ FD = factor de concentración para el método.

recuperación altos y comparables en las diferentes determinaciones, como se muestra en las tablas 1 y 2.

\section{Resultados y discusión}

Las representaciones gráficas de la relación entre las concentraciones de los metales pesados y la salinidad (figs. 2-9) muestran, para cada punto en la escala de salinidad, las concentraciones de los diferentes metales en cada una de las tres fracciones aisladas en la secuencia de columnas de resinas, y las concentraciones totales (sumas de las áreas) dadas por el contorno superior. Los cuatro primeros puntos corresponden a las estaciones ubicadas dentro del Río Manzanares, el penúltimo enfrente del río (interfase de agua río-mar) y el último al extremo marino. Los puntos entre el extremo fluvial y enfrente del río corresponden a la zona de mezcla o pluma.

\section{Cadmio}

El cadmio en la fracción disuelta fue detectado principalmente durante el periodo de lluvia de 1996 únicamente en la fracción obtenida en la resina de intercambio iónico (D3) la cual retiene los metales pesados en su forma libre o hidratada. Este metal presentó un comportamiento no conservativo con concentraciones que variaron entre no detectado y $0.010 \mu \mathrm{mol}$ $\mathrm{L}^{-1}$ para el mes de septiembre y entre no detectado y $0.012 \mu \mathrm{mol} \mathrm{L}{ }^{-1}$ en noviembre (fig. 2). En septiembre, todo el Cd presente en las aguas del río se encuentra asociado al MES observándose aportes del metal en toda la zona de mezcla, lo que puede estar indicando la desorción del Cd del MES posiblemente a consecuencia del intercambio del Cd adsorbido en las partículas de arcilla y materia orgánica que conforman el material en suspensión transportado por el río durante este mes correction. Quantification limits were determined according to the expression:

$$
\text { Quantification limit }=(\hat{a}+10 * \sigma) / F D
$$

where â is the average blank readout, $\sigma$ is the standard deviation of the blank $(n=15)$, and FD is the concentration factor for the method.

Since no water sample containing colloidal materials and dissolved organic matter similar to that of the Manzanares River could be prepared, the accuracy of the method for the Chelex-100 resin was tested. This technique was tested by Lewis and Landing (1992), who obtained reproducible results. The standard deviation values were very low and the recovery percentages were high and somewhat similar in the different assays, as shown in tables 1 and 2 .

\section{Results and discussion}

The schematics representing the relation between the heavy metal concentrations and salinity (figs. 2-9) show, for each point in the salinity scale, the different metal concentrations in each of the three fractions isolated in the resin-packed column sequence, and the total concentration (sum of the areas) given by the upper contour. The first four points correspond to the stations located upriver, the penultimate to the river front or riverine-marine water interface, and the last to the marine end. The points spanning the fluvial end and the front correspond to the mixing area, or plume.

\section{Cadmium}

The Cd of the dissolved phase was detected primarily during the 1996 rainy season only in the fraction obtained from 
y, por otra parte, aportes debidos a las actividades humanas que se desarrollan en la zona. Comber et al. (1995) en los estuarios de Humber y Mersey (UK), y Owens et al. (1997) en el estuario de Forth (UK), atribuyeron la disminución en la concentración de Cd en el MES de las aguas a la desorción del metal para formar complejos solubles con los cloruros a salinidades intermedias y alta. En noviembre se observa el mismo comportamiento, con un pequeño aporte desde el extremo fluvial.

En enero de 1997 se presentaron concentraciones de Cd en una proporción mucho menor que en septiembre y noviembre, con aportes tanto en el extremo fluvial como en la zona de mezcla y no se detectó Cd en el extremo marino, observándose niveles del metal entre no detectado y $0.002 \mu \mathrm{mol} \mathrm{L}^{-1}$ para la fracción D1 y entre no detectado y $0.001 \mu \mathrm{mol} \mathrm{L}^{-1}$ para la fracción D2. En ese mes no se detectó Cd en la fracción D3. Estos resultados pueden deberse al dragado que se estaba realizando en esa época cerca de la desembocadura del río, el cual origina la resuspensión de los sedimentos del fondo liberando al agua los coloides de oxihidróxido y sulfuros metálicos y las sustancias húmicas polianiónicas atrapadas en los sedimentos.

Márquez (1997) no detectó Cd disuelto en esta zona en 1995 y asumió que dicho metal se encuentra preferentemente asociado al material en suspensión y posiblemente a los compuestos de Fe, Mn y Zn. De igual manera, Elbaz-Poulichet et al. (1996) han evidenciado distribuciones conservativas y movilizaciones del Cd disuelto en la pluma superficial del Río Rhöne (Francia), mientras que Garnier y Guieu (2003) han observados diferentes comportamientos en sistemas estuarinos, desde conservativo a no conservativo, dependiendo de los efectos cinéticos ligados con el tiempo de residencia y la naturaleza del material en suspensión.

\section{Cinc}

El cinc en la fracción disuelta presenta un comportamiento no conservativo con las mayores concentraciones de dicho metal durante el periodo de lluvia (fig. 3). En septiembre se observaron concentraciones que oscilaron entre no detectado y $2.36 \mu \mathrm{mol} \mathrm{L} \mathrm{L}^{-1}$ para la fracción D1, no detectado y $1.49 \mu \mathrm{mol}$ $\mathrm{L}^{-1}$ para D2 y entre $0.08 \mu \mathrm{mol} \mathrm{L}^{-1}$ y $1.37 \mu \mathrm{mol} \mathrm{L}^{-1}$ para D3. De igual manera se presenta un aumento de las concentraciones del metal entre salinidades de 0.10 y 10.00 , así como aportes de este elemento en toda la zona de mezcla pero en menor escala. Este aumento del Zn puede ser una consecuencia de la desestabilización de la solución debido al aumento de la fuerza iónica, producto del aumento de sales en las aguas, ocurriendo el intercambio de los metales pesados adsorbidos en las partículas de arcilla y materia orgánica por el sodio presente en el agua de mar.

Por otro lado, dicha desestabilización igualmente provoca la floculación de las sustancias disueltas y formación de oxihidróxidos de hierro y manganeso con coprecipitación de otros metales pesados tales como $\mathrm{Zn}$, Cu y Cr. Además, las aguas de río son ricas en materia orgánica de origen vegetal que al the ion exchange resin (D3). The heavy metals thus withheld, in free or hydrated form, showed a nonconservative behavior, with concentrations ranging from undetected to $0.010 \mu \mathrm{mol} \mathrm{L}^{-1}$ in September and from undetected to $0.012 \mu \mathrm{mol} \mathrm{L}^{-1}$ in November (fig. 2). In September, all the $\mathrm{Cd}$ in the river water was associated with the particulate matter, the metal contributions being apparent throughout the mixing zone, suggestive of Cd desorbed from the suspended matter, possibly as a consequence, on the one hand, of interactions between the $\mathrm{Cd}$ adsorbed to clay particles and organic matter that comprise the material in suspension carried by the river and, on the other, of the anthropogenic contributions from the area. Comber et al. (1995), in the Humber and Mersey Estuaries (UK), and Owens et al. (1979), in the Forth Estuary (UK), attributed the decrease in Cd concentration in the suspended matter to desorption of the metal to form soluble complexes with chlorides at
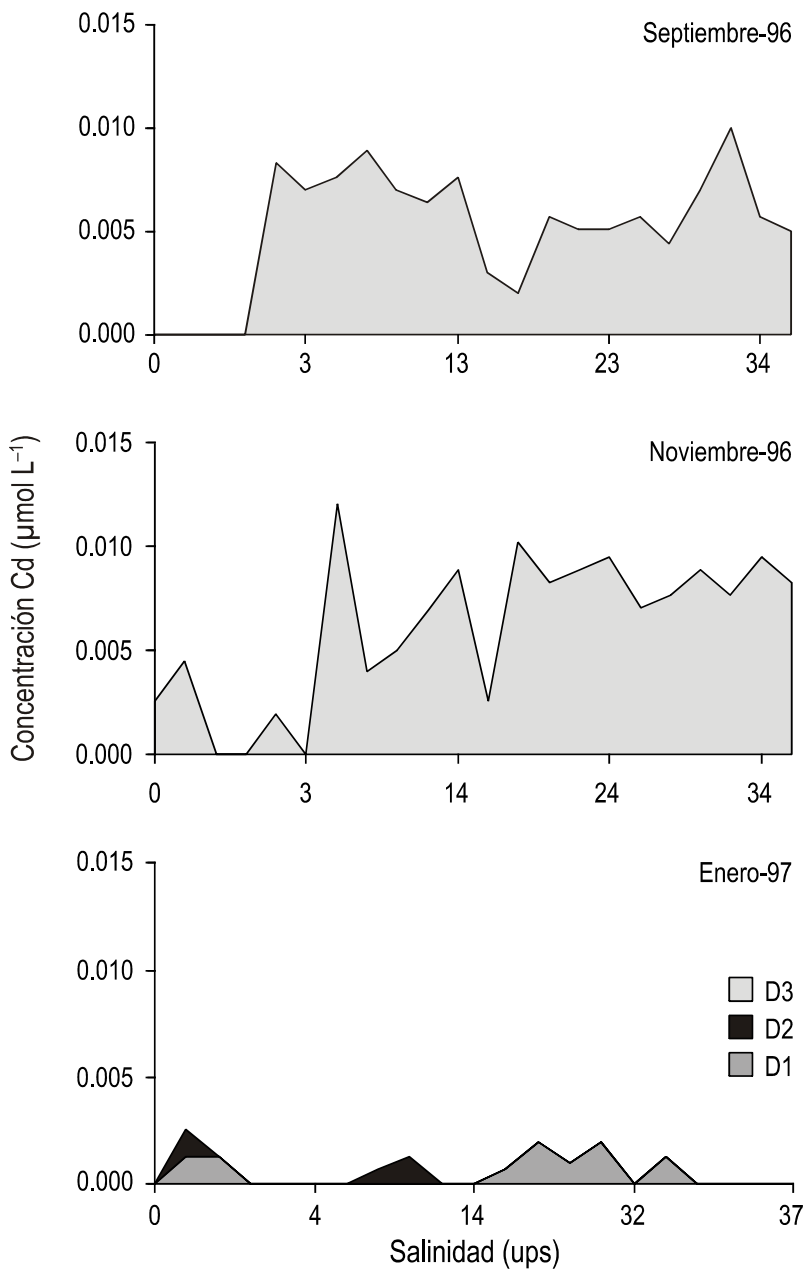

Figura 2. Relación entre la concentración ( $\left.\mu \mathrm{mol} \mathrm{L}^{-1}\right)$ de cadmio en las tres fracciones extraídas de la porción disuelta y la salinidad en las aguas superficiales del Río Manzanares y su pluma.

Figure 2. Relation between the concentration $\left(\mu \mathrm{mol} \mathrm{L}^{-1}\right)$ of cadmium in the three fractions extracted from the dissolved portion and the salinity in surface waters of the Manzanares River and its plume. 
descomponerse producen ácidos húmicos tales como el ácido fúlvico, el cual puede complejarse con los metales pesados que se encuentran libres e hidratados en el agua del ecosistema.

En noviembre se presentan aportes de $\mathrm{Zn}$ desde el extremo fluvial, los cuales disminuyen rápidamente entre el extremo fluvial y 2.50 psu de salinidad, y luego se incrementan hacia las $12.00 \mathrm{psu}$. Las concentraciones en ese mes variaron desde $0.45-3.04 \mu \mathrm{mol} \mathrm{L}^{-1}$ para el Zn asociado a D1, entre 0.31-0.94 $\mu \mathrm{mol} \mathrm{L} \mathrm{L}^{-1}$ para D2 y entre $0.01-0.35 \mu \mathrm{mol} \mathrm{L}{ }^{-1}$ para D3; mientras que en el extremo marino no se detectaron concentraciones para las dos primeras fracciones y se detectaron de $0.33 \mu \mathrm{mol}$ $\mathrm{L}^{-1}$ para D3. La disminución de las concentraciones de este metal en los primeros momentos de las mezclas corresponde a la floculación de los metales disueltos, mientras que el aumento de las concentraciones puede ser debido al aumento de las partículas y complejos metal-material húmico que se producen al liberarse los metales adsorbidos en el material en suspensión transportados por el río. Al mismo tiempo, se intermediate and high salinities. The same behavior is observed in November, with a small contribution from the fluvial end.

The January 1997 data revealed Cd concentrations in smaller proportions than those of September and November, with contributions both in the fluvial end and in the transition zone between fresh and marine waters, Cd being undetected in the marine front. The Cd concentrations ranged from below detection to $0.002 \mu \mathrm{mol} \mathrm{\textrm {L } ^ { - 1 }}$ for the D1 fraction, and from below detection to $0.001 \mu \mathrm{mol} \mathrm{L}^{-1}$ for the $\mathrm{D} 2$ fraction. This metal was not detected in the D3 fraction for that month. These results may be due to the dredging carried out in the proximity of the river mouth at that time. Dredging resuspends sediments, liberating oxyhydroxide and metallic sulfur colloids and sediment-trapped humic polyanion substances into the water. Márquez (1997) did not detect any dissolved Cd in this zone in 1995, assuming it to be associated with the suspended matter and probably with Fe, Mn, and Zn. Likewise, Elbaz-Poulichet et al. (1996) documented mobilizations and conservative
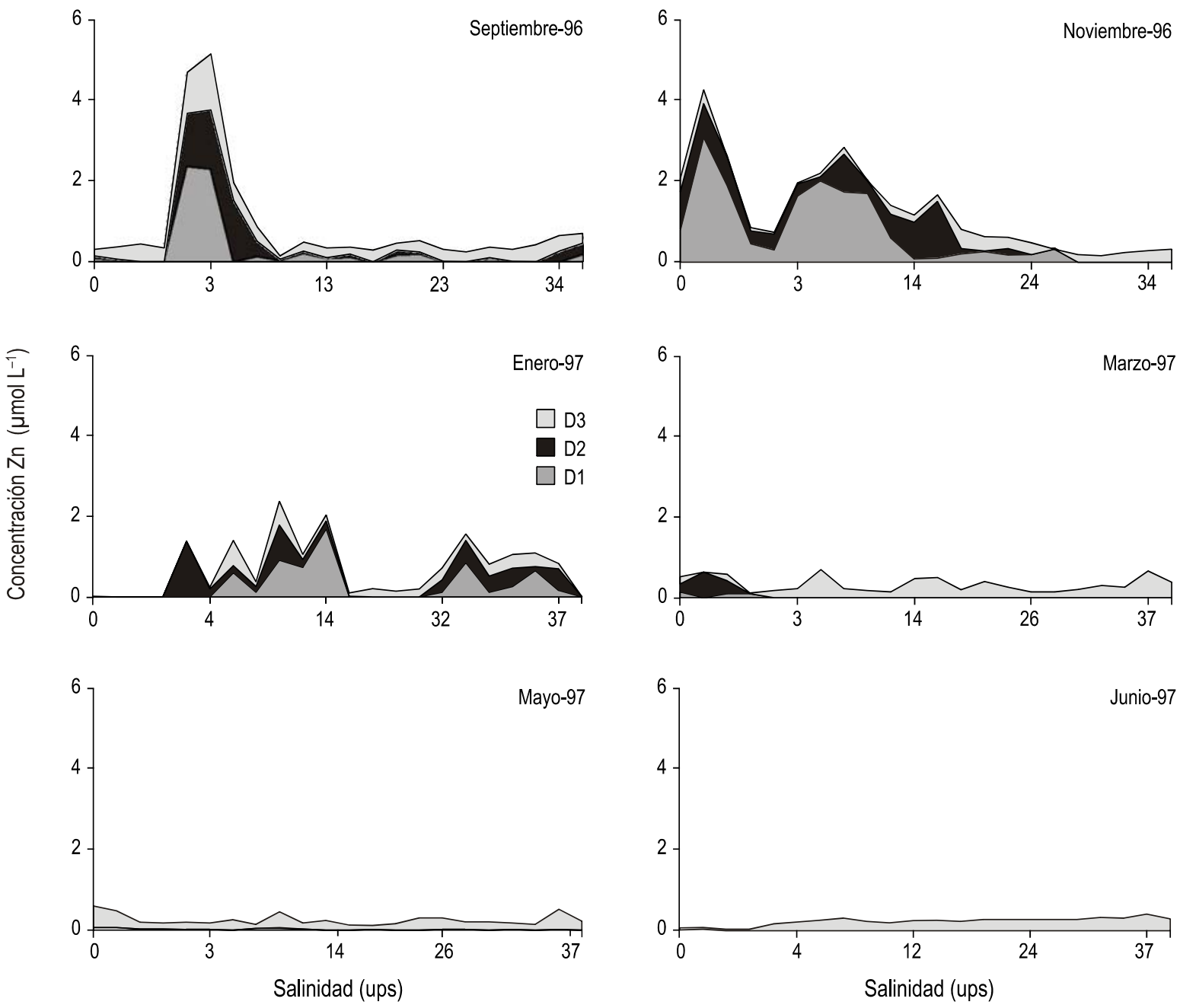

Figura 3. Relación entre la concentración ( $\mu \mathrm{mol} \mathrm{L}^{-1}$ ) de cinc en las tres fracciones extraídas de la porción disuelta y la salinidad en las aguas superficiales del Río Manzanares y su pluma.

Figure 3. Relation between the concentration $\left(\mu \mathrm{mol} \mathrm{L}^{-1}\right.$ ) of zinc in the three fractions extracted from the dissolved portion and the salinity in surface waters of the Manzanares River and its plume. 
observa una fuerte remoción del Zn en su fracción asociada a las partículas coloidales de oxihidróxidos de Fe y Mn. No obstante, las concentraciones de Zn libre o hidratado están sujetas a procesos de remoción o adición que ocurren en el material particulado debido a los aportes antropogénicos que se producen en la zona.

Durante el período de sequía las concentraciones de $\mathrm{Zn}$ disuelto estuvieron en un rango entre no detectado y 1.698 $\mu \mathrm{mol} \mathrm{L}{ }^{-1}$ para D1, no detectado y $1.386 \mu \mathrm{mol} \mathrm{L}^{-1}$ para D2, y no detectado y $0.664 \mu \mathrm{mol} \mathrm{L} \mathrm{L}^{-1}$ para D3, con concentraciones máximas en enero, cuando se iniciaron las labores de dragado muy cerca de la desembocadura del río. Este dragado se realiza cada dos años aproximadamente en la rala de la empresa Varaderos Caribe y en la entrada al puerto pesquero de Cumaná. En marzo y mayo las concentraciones de Zn son más bajas pero se nota la adición de $\mathrm{Zn}$ libre e hidratado producto de la resuspensión de los sedimentos del fondo por el dragado. Durentae estos meses se observan valores altos de Zn hacia el extremo marino, posiblemente relacionados con el fenómeno de surgencia o afloramiento de agua sub-superficial desde la Fosa de Cariaco que sucede durante este período del año, fertilizando la costa nororiental de Venezuela y muy marcado en la región del Golfo de Cariaco (Okuda et al. 1978, Thunell et al. 2000).

Márquez et al. (2000) encontraron un comportamiento no conservativo del Zn disuelto en el Río Manzanares, con adición del metal a bajas salinidades y remoción a salinidades superiores a 7 unidades, con concentraciones que permanecen casi constantes durante todo el año, comportamiento atribuible a la capacidad que tiene este metal para formar óxidos coloidales que permanecen en solución sin precipitar. El $\mathrm{pH}$ parece estar jugando un papel importante en la distribución y precipitación del cinc disuelto en la zona estuarina del Río Manzanares. Hahne y Kroontje (1973) señalaron que este metal se hidroliza a pH mayores de 7, formando compuestos de hidróxido de gran estabilidad a $\mathrm{pH}$ superior a 8.

En muchos estuarios se han citado resultados muy contradictorios para el comportamiento del Zn. Duinker y Nolting (1978) reportaron una disminución en las concentraciones de Zn debida a la adsorción de partículas y a cambios en la especiación de este elemento. Morse et al. (1993) reportaron comportamiento conservativo del Zn en la Bahía de Galveston, e indicaron que los excesos del metal disuelto son debidos a procesos de dilución en el agua dulce y decrecimiento en los acomplejamientos del metal. De igual manera, Song y Müller (1995) determinaron valores considerables de Zn disuelto en el Río Neckar (Alemania), debido a la liberación desde los sulfuros metálicos y la biomasa.

Cobre

Los resultados obtenidos para el cobre disuelto están representados en la figura 4 . Se observó un comportamiento no conservativo con remoción a bajas salinidades, encontrándose las mayores concentraciones durante el período de lluvia, específicamente en septiembre, cuando los valores oscilaron entre no detectado y $0.030 \mu \mathrm{mol} \mathrm{L} \mathrm{L}^{-1}$ para el $\mathrm{Cu}$ contenido en la distributions of Cd in the surface-trapped plume of the Rhone River (France), while Garnier and Guieu (2003) observed different behaviors, ranging from conservative to nonconservative, in estuarine systems, depending on the kinetic effects associated with the nature and residence time of the suspended matter.

Zinc

The $\mathrm{Zn}$ in the dissolved fraction presents a nonconservative behavior, the largest concentrations occurring during the rainy season (fig. 3). The month of September evidenced concentrations ranging from below detection levels to $2.36 \mu \mathrm{mol} \mathrm{L}^{-1}$ for $\mathrm{D} 1$, from below detection to $1.49 \mu \mathrm{mol} \mathrm{L}^{-1}$ for $\mathrm{D} 2$, and from 0.08 to $1.37 \mu \mathrm{mol} \mathrm{L}^{-1}$ for D3. Small-scale contributions of this element and concentration increments are produced for salinities ranging between 0.10 and $10.00 \mathrm{psu}$. This $\mathrm{Zn}$ increase may be a consequence of the destabilization of the solution on account of the stronger ion force exerted by the augmented amount of salts in the water when the heavy metals adsorbed to the clay particles and to the organic matter are exchanged for $\mathrm{Na}$ in seawater.

On the other hand, this destabilization elicits flocculation of the substances dissolved, as well as the formation of Fe and Mn oxyhydroxides with precipitation of other heavy metals such as $\mathrm{Zn}, \mathrm{Cu}$, and $\mathrm{Cr}$. Besides, river waters are rich in organic matter of vegetable origin, which, upon decomposition, produces humic acids such as fulvic acid. The latter, in turn, may form complexes with the free and hydrated heavy metals present in the water of the ecosystem.

In November, $\mathrm{Zn}$ is contributed from the fluvial end, decreasing rapidly at 2.50 psu of salinity and increasing again towards $12.00 \mathrm{psu}$. Concentrations for this month fluctuated between 0.45 and $3.04 \mu \mathrm{mol} \mathrm{L}^{-1}$ for the Zn associated with D1, between 0.31 and $0.94 \mu \mathrm{mol} \mathrm{L}^{-1}$ for D2 and between 0.01 and $0.35 \mu \mathrm{mol} \mathrm{L}^{-1}$ for $\mathrm{D} 3$, while concentrations at the marine front were undetected for the first two fractions and $0.33 \mu \mathrm{mol} \mathrm{L}^{-1}$ for D3. The decrease in concentration for this metal during the first stages of the mixing is due to flocculation of the dissolved metals, while the increase in concentrations may be attributed to a progressively greater amount of particulate and metalhumic material complexes produced upon liberation of the metals adsorbed to the river-borne suspended matter. A strong $\mathrm{Zn}$ removal is seen in the $\mathrm{Zn}$ fraction bound to the Fe and $\mathrm{Mn}$ colloidal oxyhydroxide particles. However, the free or hydrated Zn concentrations are subject to removal or aggregation processes occurring in the particulate material because of the anthropogenic contributions produced in this area.

During the dry season, the concentrations of dissolved Zn ranged from undetected to $1.698 \mu \mathrm{mol} \mathrm{L}^{-1}$, from undetected to $1.386 \mu \mathrm{mol} \mathrm{L}^{-1}$, and from undetected to $0.664 \mu \mathrm{mol} \mathrm{L}^{-1}$ for D1, D2, and D3, respectively, the highest concentration occurring in January, when dredging operations started near the river mouth. Dredging is carried out about every two years along the wharf of a nearby shipyard and in the inlet harboring the 
fracción D1, no detectado y $0.053 \mu \mathrm{mol} \mathrm{\textrm {L } ^ { - 1 }}$ para el $\mathrm{Cu}$ asociado a D2, y entre 0.003 y $0.060 \mu \mathrm{mol} \mathrm{L}^{-1}$ para el Cu libre o "hidratado". Se observan aportes de $\mathrm{Cu}$ disuelto desde el río con remoción a bajas salinidades y adición del metal a lo largo de la pluma, especialmente en la fracción D3. En el período de sequía, se presenta adición del metal a lo largo de la región de mezcla, posiblemente producto del dragado de la zona y a los aportes debidos a las diferentes actividades industriales y urbanas que se desarrollan en la zona.

León (1995) y Márquez et al. (2000) observaron el mismo comportamiento no conservativo del $\mathrm{Cu}$ disuelto en la cuenca baja y pluma del Río Manzanares, que sugiere una remoción a bajas salinidades con formación de óxidos coloidales de hierro y manganeso que pueden permanecer más tiempo en suspensión. Estas partículas en suspensión pueden pasar a través de un filtro Millipore HAWP con aberturas de poros de $0.45 \mu \mathrm{m}$ y ser determinadas en la fracción disuelta. Song y Müller (1995), trabajando en el estuario del Río Neckar, reportaron que el Cu disuelto fue adsorbido por los óxidos de hierro floculados y las sustancias húmicas durante la mezcla estuarina y señalaron que las especies iónicas libres son muy sensibles a la complejación y las proporciones tienden a reducirse por ausencia de quelatos y a ser aumentadas por su liberación a partir de los sulfuros metálicos. Se han señalado comportamientos no conservativos para el $\mathrm{Cu}$ en los estuarios Jiulungjiang, Minjiany y Huanghe en China (Zhang 1995). Paulson et al. (1991) señalaron que la descomposición de la materia orgánica y el intercambio de iones controlan la liberación de alrededor de una tercera parte del Cu enlazado a partículas superiores a $53 \mu \mathrm{mol} \mathrm{L}^{-1}$ mientras que las más pequeñas liberan alrededor del $5 \%$ del Cu disuelto en agua de mar artificial con concentraciones de metal muy bajas. De igual manera, Dassenakis et al. (1997) señalan que los metales disueltos son adsorbidos significativamente en las partículas transportadas por los ríos, y que la existencia de grandes cantidades de partículas están asociadas comúnmente con disminuciones en las formas disueltas, al igual que la desorción de los metales del MES en el agua de mar, bajo la acción del intercambio de iones de los cationes en concentraciones mayores ( $\mathrm{Na}, \mathrm{K}$, Ca y $\mathrm{Mg}$ ), resulta en el incremento de las concentraciones de los metales disueltos a salinidades intermedias en las regiones costeras.

\section{Cromo}

Durante el periodo de lluvia no se detectó cromo en la fracción disuelta. Esto puede ser debido a que dicho elemento se encuentra preferentemente asociado al material en suspensión, formando parte de los minerales de arcilla, y a los compuestos sólidos de Fe y Mn, alcanzando para septiembre de 1996 una concentración de $2.00 \mu \mathrm{mol} \mathrm{L}{ }^{-1}$ en el MES (Martínez y Senior 2001). En marzo, durante el período de sequía (fig. 5), el Cr se determinó en la zona aledaña al Puente Raúl Leoni (estación 1) para la fracción D1 $\left(0.008 \mu \mathrm{mol} \mathrm{L} \mathrm{L}^{-1}\right)$ y en la región de mezcla de las aguas de río y mar a partir de las 2.250 ups en la fracción fishing fleet. In March and May, Zn concentrations are lower, but the additional free and hydrated $\mathrm{Zn}$ stirred up by the dredging is noticeable. High values of $\mathrm{Zn}$ are observed along the marine front during these months, a phenomenon quite marked in the gulf area, possibly in connection with the upwelling of the Cariaco Trench subsurface water during this time of the year, which fertilizes the northeastern coast of Venezuela (Okuda et al. 1978, Thunell et al. 2000).

Márquez et al. (2000) found a nonconservative behavior for the Manzanares River dissolved Zn, the metal being added at lower salinities and removed at salinities greater than 7 psu. The concentrations of Zn remain almost constant throughout the year, a behavior attributed to its capacity to form colloidal oxides that linger in the solution without precipitating. The $\mathrm{pH}$ seems to play an important role in the distribution and precipitation of the $\mathrm{Zn}$ dissolved in the estuarine zone of the Manzanares River. Hahne and Kroontje (1973) pointed out that this metal becomes hydrolyzed at a $\mathrm{pH}$ greater than 7 , forming highly stable hydroxide compounds at $\mathrm{pH}$ values above 8 .

Many estuaries have revealed contradictory results for $\mathrm{Zn}$ behavior. A decrease in concentration has been reported by Duinker and Nolting (1978) because of particulate adsorption and changes in Zn speciation. Morse et al. (1993) reported a conservative behavior for $\mathrm{Zn}$ in Galveston Bay and indicated that the dissolved metal excess was due to dilution processes in the fresh water and to a dwindling of the metal complexation. Likewise, Song and Müller (1995) determined considerable values of dissolved $\mathrm{Zn}$ in the Neckar River as a result of release from biomass and metallic sulfurs.

\section{Copper}

The results obtained for dissolved $\mathrm{Cu}$ are shown in figure 4 . A nonconservative behavior with removal was observed at low salinities, the larger concentrations being found during the rainy season, specifically in September, when the values fluctuated between undetected and $0.030 \mu \mathrm{mol} \mathrm{L}^{-1}$ and between undetected and $0.053 \mu \mathrm{mol} \mathrm{L}^{-1}$ for the D1- and D2-bound $\mathrm{Cu}$, respectively, and between 0.003 and $0.060 \mu \mathrm{mol} \mathrm{L}^{-1}$ for the free or "hydrated" $\mathrm{Cu}$. Dissolved $\mathrm{Cu}$ is contributed from the river phase with removal at low salinities and addition of the metal along the plume, especially in the D3 fraction. During the dry season, addition of the metal is present along the mixing region, possibly resulting from the dredging of the seabed and the different industrial and urban activities carried out in the surrounding area.

León (1995) and Márquez et al. (2000) observed the same nonconservative behavior in the dissolved $\mathrm{Cu}$ of the low basin and plume of the same waterway, suggestive of removal at low salinities with formation of colloidal Fe and Mn oxides that may remain suspended for longer periods. These suspended particles can pass through a $0.45-\mu \mathrm{m}$ pore size Millipore HAWP filter and be determined in the dissolved fraction. Song and Müller (1995), working in the Neckar River estuary 

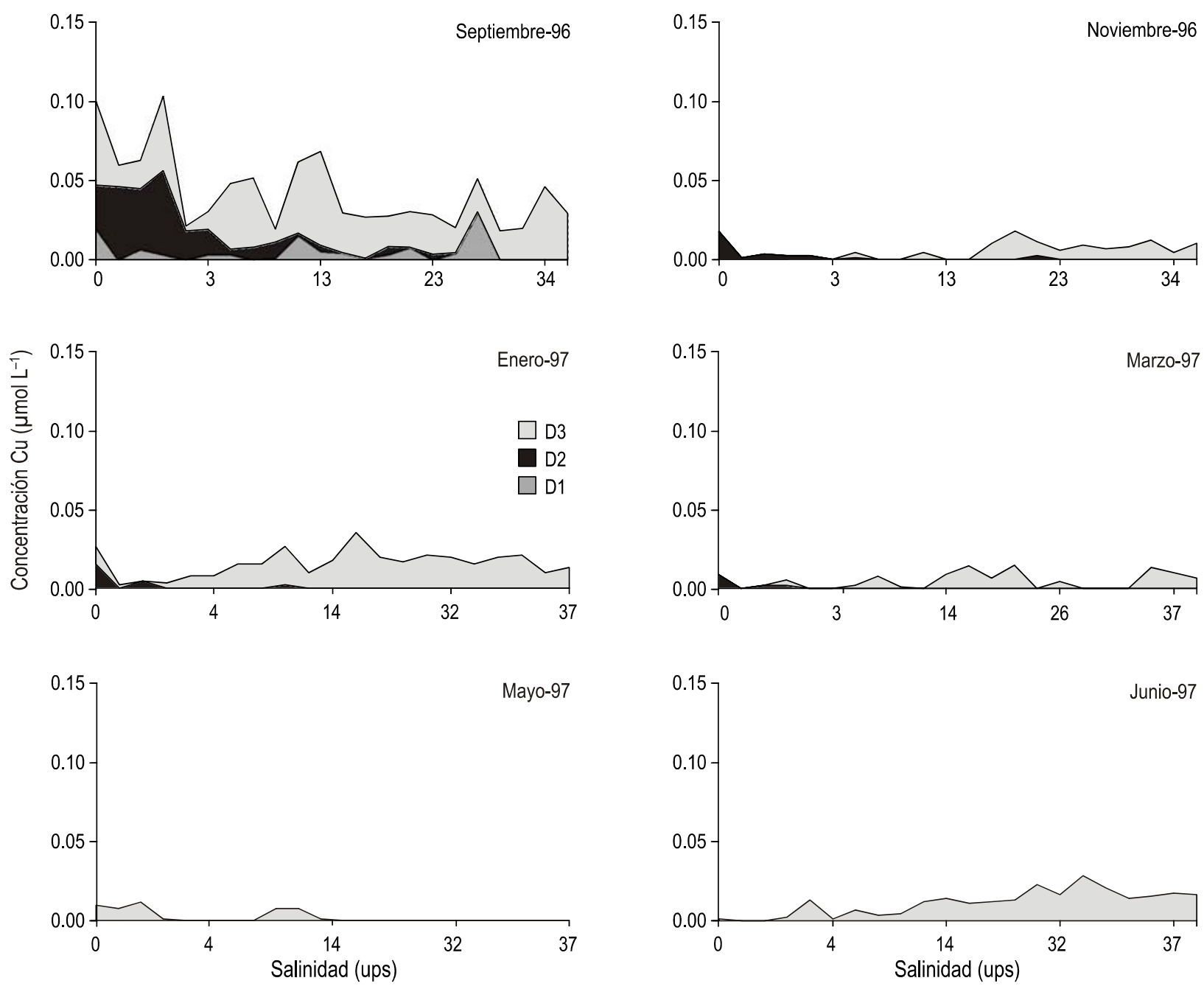

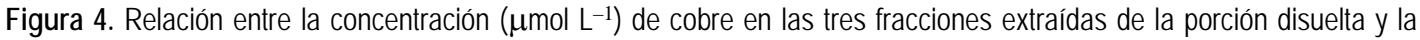
salinidad en las aguas superficiales del Río Manzanares y su pluma.

Figure 4. Relation between the concentration ( $\mu \mathrm{mol} \mathrm{L}^{-1}$ ) of copper in the three fractions extracted from the dissolved portion and the salinity in surface waters of the Manzanares River and its plume.

D3 debido a la resuspensión de los sedimentos y a la descomposición de la materia orgánica en esta zona. En Junio se observan aportes de Cr complejado con las sustancias húmicas y libre e hidratado en la región de mezcla (fracción D2), como consecuencia del inicio de las lluvias que lavan la corteza terrestre y llevan al mar todos los desechos acumulados en lagunas, caños, quebradas y canales que circundan la ciudad de Cumaná.

Márquez et al. (2000) no detectaron Cr en la fracción disuelta de las aguas durante el estudio de este ecosistema, señalando de igual manera que dicho metal se encuentra mayormente asociado al material en suspensión y los óxidos de Fe y Mn transportados por las aguas del sistema. Por otra parte, León (1995), León et al. (1997) y Martin et al. (1993) coinciden en señalar que los cambios de $\mathrm{pH}$ y salinidad conducen a la precipitación de oxihidróxidos coloidales de hierro y que el Cr precipita adherido a éstos. De igual manera Sadiq
(Germany), reported that the dissolved Cu was adsorbed by the flocculated Fe oxides and humic substances during estuarine mixing, and indicated that the free ion species were very sensitive to complexation, the proportions tending to dwindle due to a lack of chelates and to increase because of the liberation from metal sulfurs. Nonconservative behaviors for $\mathrm{Cu}$ have been reported in the estuaries of Jiulungjiang, Minjiany, and Huanghe in China (Zhang 1995). Paulson et al. (1991) indicated that the decomposition of organic matter and ion exchange control the liberation of about one-third of the $\mathrm{Cu}$ bound to particles larger than $53 \mu \mathrm{mol} \mathrm{L} \mathrm{L}^{-1}$, while only about $5 \%$ of the $\mathrm{Cu}$ dissolved in artificial seawater is liberated in very small concentrations by the smaller particles. Likewise, Dassenakis et al. (1997) claim that the dissolved metals are significantly adsorbed to river-borne particulate matter, and that the existence of great quantities of particles is commonly associated with reductions of the dissolved forms, just as the 

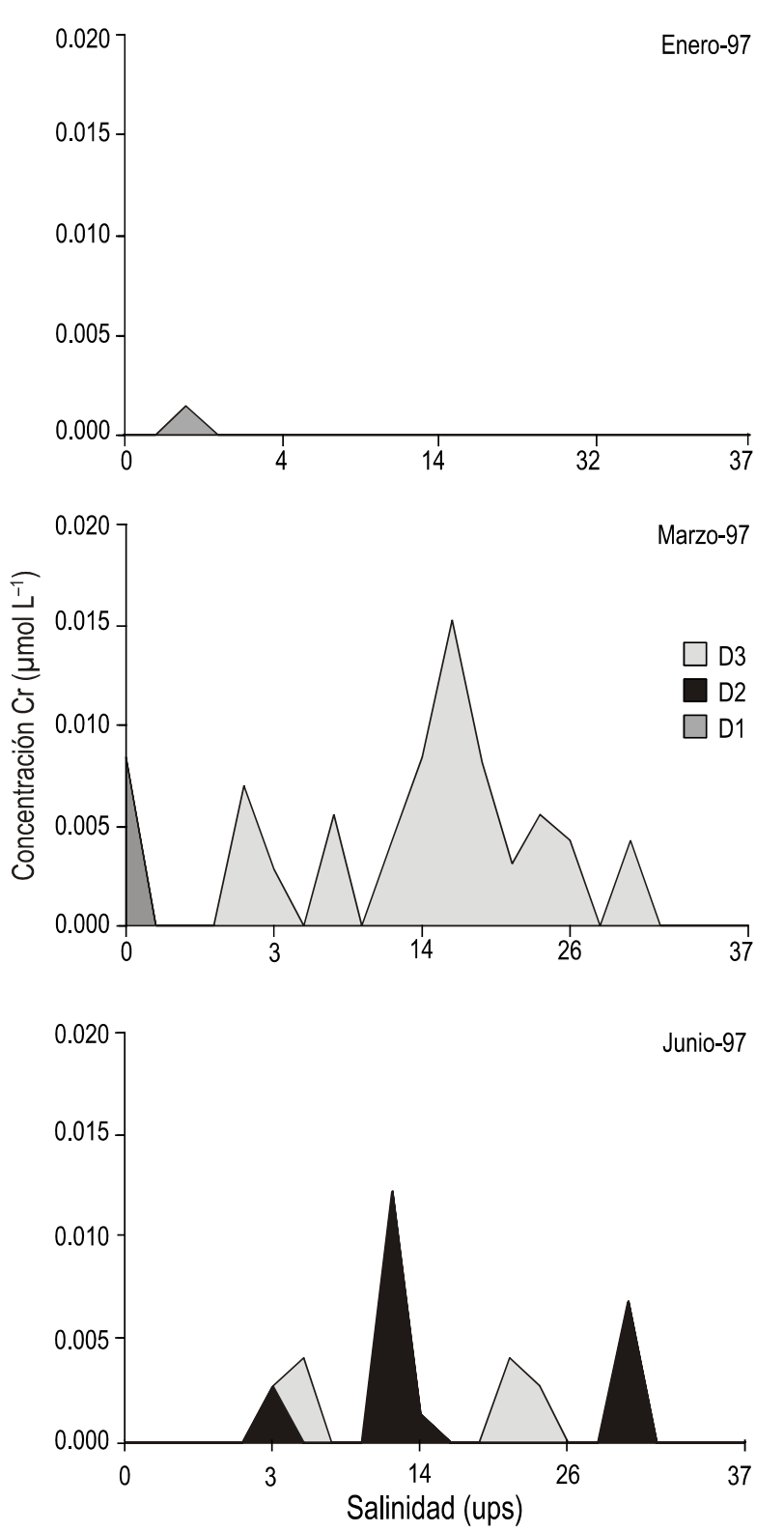

Figura 5. Relación entre la concentración $\left(\mu \mathrm{mol} \mathrm{L}^{-1}\right)$ de cromo en las tres fracciones extraídas de la porción disuelta y la salinidad en las aguas superficiales del Río Manzanares y su pluma.

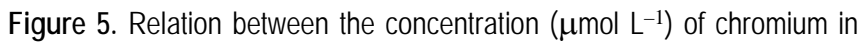
the three fractions extracted from the dissolved portion and the salinity in surface waters of the Manzanares River and its plume.

(1992), indica que el Cr muestra una marcada tendencia a ser adsorbido a bajas salinidades, especialmente en la superficie de los óxidos de hierro. Malle (1990) señala que el Cr, Hg y $\mathrm{Pb}$ son mayormente transportados en forma no disuelta, es decir con el material en suspensión, asociados a los granos más finos $(<2 \mu \mathrm{m})$.

Hierro

El hierro en la fracción disuelta (fig. 6) presenta un comportamiento no conservativo, variando sus concentraciones desorption of metals in the material suspended in seawater, swayed by larger cation exchange concentrations $(\mathrm{Na}, \mathrm{K}, \mathrm{Ca}$, and $\mathrm{Mg}$ ), results in an increase in the concentration of dissolved metals at intermediate salinities in coastal regions.

\section{Chromium}

During the rainy season, $\mathrm{Cr}$ was not detected in the dissolved fraction, possibly because of its being preferably bound to argillaceous minerals and to the solid Fe and Mn compounds in the suspended matter, where it reached a concentration of $2.00 \mu \mathrm{mol} \mathrm{L}^{-1}$ in September (Martínez and Senior 2001). This metal was determined in the area adjacent to the Raúl Leoni Bridge (fig. 1) in March during the dry season (fig. 5) for the $\mathrm{D} 1$ fraction $\left(0.008 \mu \mathrm{mol} \mathrm{L}^{-1}\right)$ and at the riverine-marine plume interface beginning at the 2.25 psu salinity gradient in the D3 fraction due to sediment resuspension and organic matter decomposition in this zone. The onset of the rainy season in June prompts the runoff that contributes $\mathrm{Cr}$ complexed with humic substances and free and hydrated $\mathrm{Cr}$ to the plume interface (fraction D2).

Márquez et al. (2000) did not detect $\mathrm{Cr}$ in the dissolved fraction of the water during their study of this ecosystem, reporting that this metal was mainly bound to the suspended matter and to the water-borne Fe and Mn oxides. León (1995), León et al. (1997), and Martin et al. (1993) all agree that the changes in $\mathrm{pH}$ and salinity elicit colloidal $\mathrm{Fe}$ oxyhydroxide precipitation, the adhered $\mathrm{Cr}$ precipitating as well. Sadiq (1992) also indicated that $\mathrm{Cr}$ tends to adsorb at low salinities, especially to the surfaces of Fe oxides. Malle (1990) indicated that $\mathrm{Cr}, \mathrm{Hg}$, and $\mathrm{Pb}$ are mainly transported in nondissolved form, that is, bound to the $(<2 \mu \mathrm{m})$ of the suspended matter.

\section{Iron}

September marked the river's largest outflow for 1996, most Fe being concentrated in the fluvial front of the plume. During this month, the Fe of the dissolved fraction (fig. 6) exhibited a nonconservative behavior, its concentrations ranging from below detection levels to $0.482 \mu \mathrm{mol} \mathrm{L}^{-1}$, from 0.022 to $0.391 \mu \mathrm{mol} \mathrm{L}^{-1}$, and from 0.081 to $1.948 \mu \mathrm{mol} \mathrm{L}^{-1}$ for $\mathrm{D} 1$, D2, and D3, respectively. November was characterized by Fe contribution permeating the whole length of the plume.

Larger concentrations were detected in March, at the peak of the dry season, Fe exhibiting a nonconservative behavior and little removal at low salinities and contributions throughout the mixing area, possibly due to dredging, colloidal Fe oxyhydroxide formation, and organic matter decomposition, as well as to desorption processes from the suspended matter (Aston and Chester 1973), or diagenetic events and diffusion from the water-sediment interface. In May, when the river outflow is minimal, Fe contributions range from below detection levels to $0.105,0.041$ and $0.035 \mu \mathrm{mol} \mathrm{L}^{-1}$ for D1, D2, and D3, respectively, the largest concentrations being found in the fluvial end. No Fe was detected at salinities above 13.00 psu. As a consequence of the arrival of the rains, only irregular Fe-humic 

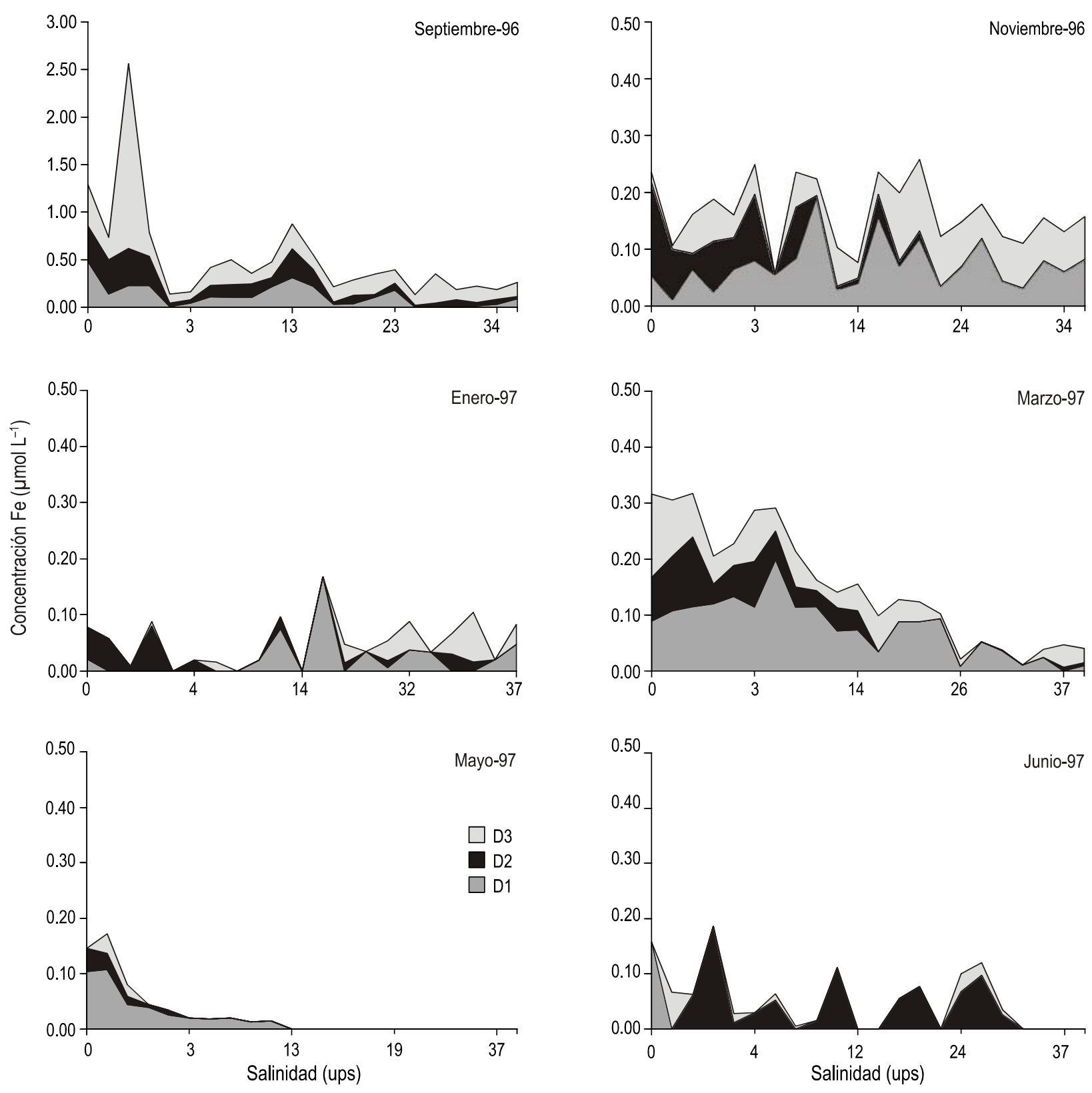

Figura 6. Relación entre la concentración $\left(\mu \mathrm{mol} \mathrm{L}^{-1}\right)$ de hierro en las tres fracciones extraídas de la porción disuelta y la salinidad en las aguas superficiales del Río Manzanares y su pluma.

Figure 6. Relation between the concentration $\left(\mu \mathrm{mol} \mathrm{L}^{-1}\right)$ of iron in the three fractions extracted from the dissolved portion and the salinity in surface waters of the Manzanares River and its plume.

entre no detectado y $0.482 \mu \mathrm{mol} \mathrm{L}{ }^{-1}$ para la fracción D1, entre 0.022 y $0.391 \mu \mathrm{mol} \mathrm{L^{-1 }}$ para la fracción D2 y entre 0.081 y $1.948 \mu \mathrm{mol} \mathrm{L}^{-1}$ para D3 en el mes septiembre, cuando se produce el mayor gasto del río en 1996, observándose mayores concentraciones de Fe disuelto en el extremo fluvial. En noviembre se observó aporte del metal a todo lo largo de la pluma del río.

En el período de sequía las mayores concentraciones se detectan en marzo, con un comportamiento no conservativo del metal con una pequeña remoción a bajas salinidades y aportes acid complexes and free and hydrated Fe contributions are noticed.

The dry season is characterized by low $\mathrm{pH}$ values, high temperatures, and increased ammonium concentrations, especially in May, when waters reach a longer residence time that accelerates the decomposition of the organic matter in water and sediments. Likewise, the behavior of dissolved Fe, in relation to $\mathrm{pH}$ (fig. 3), shows that at a $\mathrm{pH}<8$, this metal remains in solution, its precipitation occurring at higher values. Huang et al. (1992) and Zhang (1995) pointed out that 
a todo lo largo de la región de mezcla, lo cual puede ser producto del dragado de la zona, la formación de oxihidróxido de Fe coloidal y la descomposición de la materia orgánica, así como de procesos de desorción a partir del material en suspensión (Aston y Chester 1973) o procesos de diagénesis y la difusión desde la interfase agua-sedimento. En mayo, cuando el gasto del río se hace mínimo, las concentraciones del metal se encuentran en un rango entre no detectado y $0.105 \mu \mathrm{mol} \mathrm{L}^{-1}$ para D1, no detectado y $0.041 \mu \mathrm{mol} \mathrm{L}^{-1}$ en la fracción D2 y no

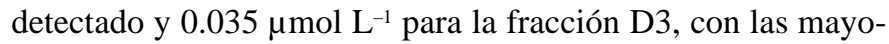
res concentraciones en el extremo fluvial y no detectándose presencia de Fe a partir de 13.00 ups. Para junio se observan aportes irregulares de este metal solamente en las fracciones de los complejos Fe-ácidos húmicos y en el Fe libre e hidratado, como consecuencia de la llegada de las lluvias que lavan la corteza terrestre arrastrando todas las sustancias acumuladas sobre superficie terrestre hacia el mar.

Durante el período de sequía existen menores valores de $\mathrm{pH}$, altas temperaturas y concentraciones de amonio específicamente durante el mes de mayo, y un mayor tiempo de residencia de las aguas que acelera los procesos de descomposición de la materia orgánica presente en agua y sedimentos. De igual manera, el comportamiento del Fe disuelto, en función del $\mathrm{pH}$ (fig. 3), muestra que a $\mathrm{pH}$ menor de 8.00 unidades el metal permanece en solución, produciéndose la precipitación del mismo a valores mayores. Huang et al. (1992) y Zhang (1995), señalaron que los óxidos e hidróxidos de aluminio pueden ser retenidos en los sedimentos, pero que los óxidos e hidróxidos de otros metales pueden ser removidos de la fase sólida hacia la solución, mientras que Zhang (1995) igualmente señala que el Fe se regenera a la columna de agua por diagénesis en el Estuario Changjiang con un 40 a $60 \%$ de Fe disuelto en la columna de agua aportado por la desorción a partir de las partículas en suspensión debido a la alta turbidez en el estuario del Río Huanghe. Elbaz-Poulichet et al. (1996) han reportado resultados similares en el Río Rhöne.

Schneider y Davey (1995) y Tsunogay y Urtmatsu (1978) señalaron que los metales acumulados en los sedimentos, incluyendo el hierro, pueden ser reintegrados a la columna de agua o ser transferidos a la biota por procesos físicos, químicos y/o biológicos, mientras que Song y Müller (1995) indican que la remineralización de la materia orgánica en el Río Neckar contribuye a los cambios en las concentraciones de muchos elementos, entre ellos el hierro, con aportes de metales disueltos hacia la columna de agua. Las remociones de hierro disuelto a bajas salinidades confirman las observaciones de Coonley et al. (1971), Holliday y Liss (1976), Bewer y Yeats (1983) y Martin et al. (1993), quienes reportaron que el hierro exhibe pérdidas a bajas salinidades, aunque algunas pérdidas han sido evidenciadas a alrededor de 20 ups (Abdullah y Boyle 1974), las cuales han sido asociadas por Dassenakis et al. (1997) con la desorción del metal debida al intercambio de cationes muy abundantes en el agua de mar. De acuerdo a estos autores, el mecanismo de remoción a bajas salinidades es la floculación de la mezcla de óxidos de hierro y manganeso con aluminum oxides and hydroxides can be retained in the sediments, but that those of other metals can be removed from the solid phase towards the solution. Zhang (1995) claims that Fe regenerates to the water column by diagenesis in the Changjiang Estuary, a 40-60\% contributed by desorption from the suspended matter that gives the river its remarkable muddiness. Similar results were reported by Elbaz-Poulichet et al. (1999) for the Rhone River.

Schneider and Davey (1995) and Tsunogay and Urtmatsu (1978) indicated that metals accumulating in the sediments, including $\mathrm{Fe}$, can be returned to the water column or transferred to the biota by means of physical, chemical, and/or biological processes. Song and Müller (1995), on the other hand, point out that the remineralization of organic matter in the Neckar River contributes to changes in the concentration of many elements, Fe among them, with dissolved metals being contributed to the water column. The removal of $\mathrm{Fe}$ at low salinities confirms the findings of Coonley et al. (1971), Holliday and Liss (1976), Bewer and Yeats (1983), and Martin et al. (1993), who reported a loss of $\mathrm{Fe}$ at low salinities, although some loss has been evident around 20 psu (Abdullah and Boyle 1974), a phenomenon that Dassenakis et al. (1997) ascribe to metal desorption due to abundant cation exchange in the ocean water. According to these authors, the removal mechanism at low salinities is the flocculation of the mixture of $\mathrm{Fe}$ and $\mathrm{Mn}$ oxides with the river-borne colloidal organic matter, upon neutralization of the latter's charge by marine cations. The $\mathrm{pH}$, although influential, seems to exert little bearing on these processes. Nonconservative behaviors at low salinities have been reported in both the dissolved fraction and the suspended matter of the Manzanares River, according to Hurtado (1986) and Márquez et al. (2000). León et al. (1997) found a similar behavior for the total concentrations of this metal.

\section{Manganese}

Dissolved Mn presented a nonconservative behavior in the study area (fig. 7), with few contributions in the fluvial front throughout both the dry and wet seasons, but with a noticeable upturn in the mixing zone. The prevailing fraction during the study was the one corresponding to D3-associated Mn, a small content of this metal being associated at low salinities with D2 throughout the rainy season and with D1 during May. The Mn content in D3 during the rainy season fluctuated between below detection and $0.260 \mu \mathrm{mol} \mathrm{L}{ }^{-1}$, the largest concentrations corresponding to September, whereas its concentration during the dry season ranged from below detection levels to a peak $1.027 \mu \mathrm{mol} \mathrm{L}^{-1}$ in May. These increases in concentration may be due to Mn desorption from the surface of the suspended particulate matter, resulting in turn from the exchange with $\mathrm{Na}^{+}$ and $\mathrm{K}^{+}$present in seawater, as the $\mathrm{Mn}$ in the suspended matter mainly finds itself either as adsorbed to the surface of the particles or as reactive Mn oxyhydroxides (Martínez and Senior 2001). 
la materia orgánica coloidal de origen fluvial, debido a la neutralización de las cargas de los coloides por los cationes marinos, mientras que el $\mathrm{pH}$, aunque influye, parece tener menor importancia en estos procesos. En el Río Manzanares se han reportado comportamientos no conservativos del Fe en las fracciones disuelta y material en suspensión con remoción a bajas salinidades en estudios efectuados por Hurtado (1986) y Márquez et al. (2000), mientras que León et al. (1997), encontraron este mismo comportamiento para las concentraciones totales de este metal.
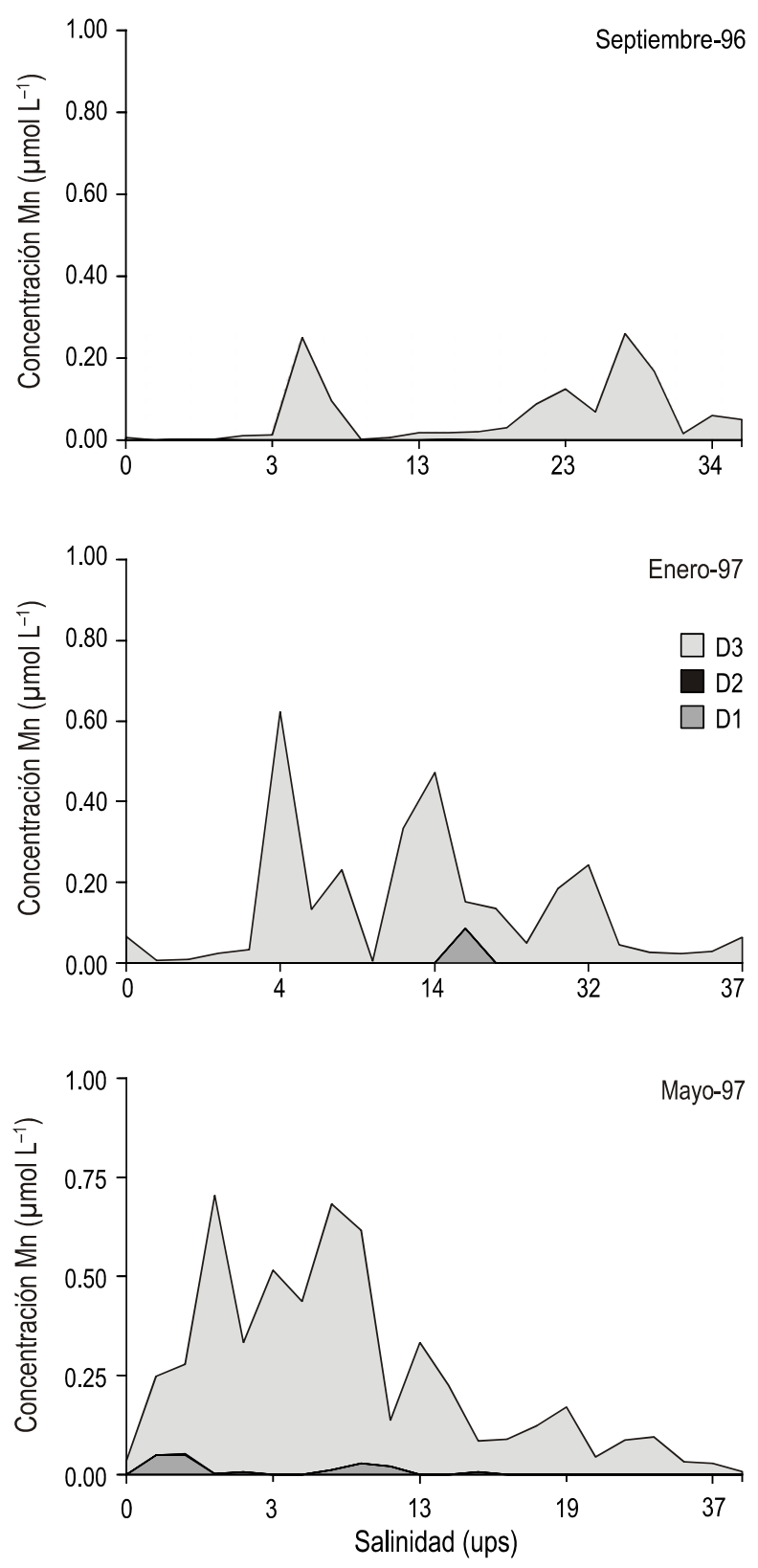

This element is quite sensitive to redox conditions, having relative mobility in marine environments. The thermodynamically stable state of $\mathrm{Mn}$ in oxygenated ocean water is insoluble $\mathrm{Mn}^{4+}$. The soluble $\mathrm{Mn}^{2+}$ is produced in reduced conditions. This metal has a slow oxidation rate; however, the unstable $\mathrm{Mn}^{2+}$ can linger in oxygenated waters for some time (Owens et al. 1997). Nonconservative distributions of this element have been reported by Wollast et al. (1979), Hart and Davis (1981), Bewer and Yeats (1983), León (1995), León et al. (1997) and Márquez (1997), who pointed out that Mn losses can occur
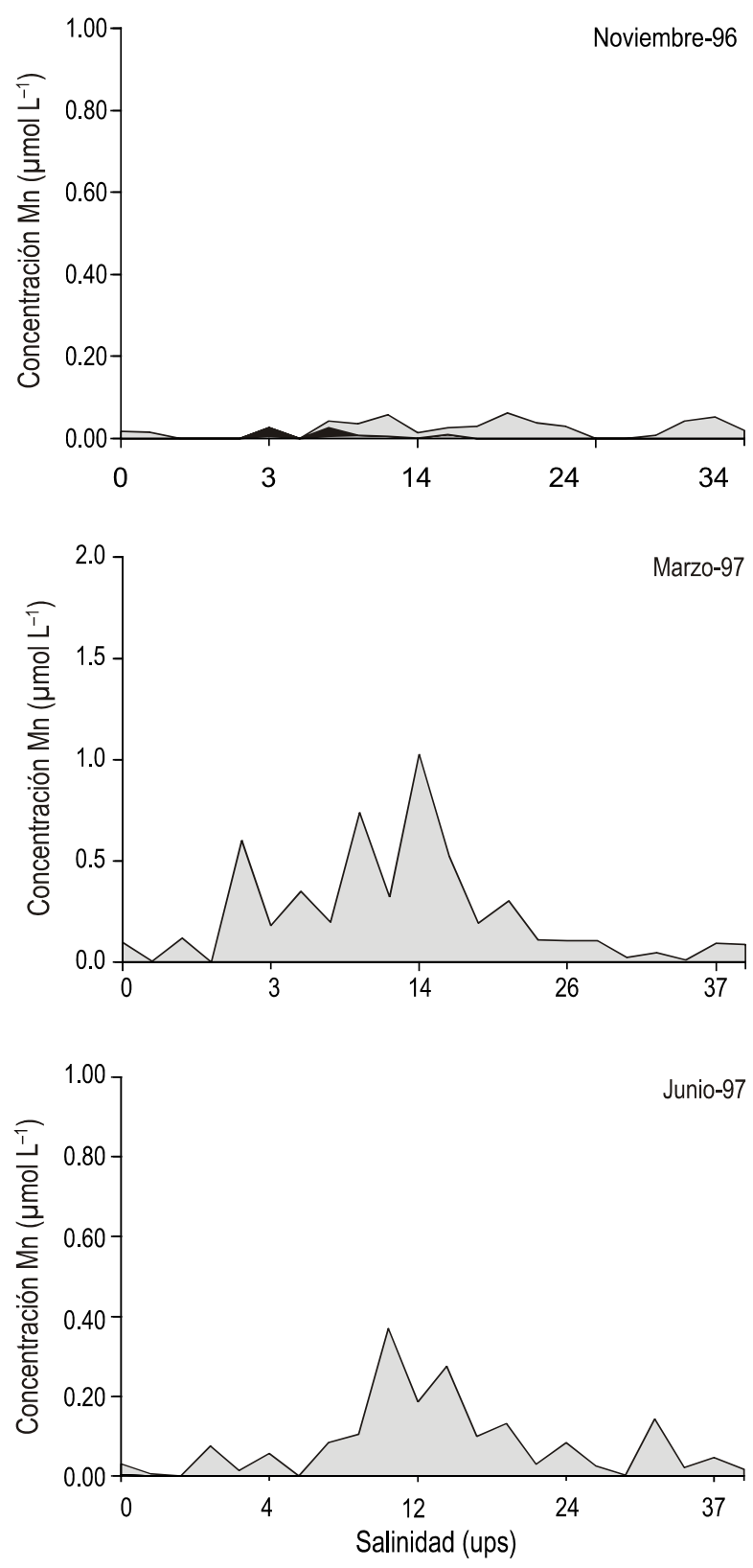

Figura 7. Relación entre la concentración $\left(\mu \mathrm{mol} \mathrm{L}{ }^{-1}\right)$ de manganeso en las tres fracciones extraídas de la porción disuelta y la salinidad en las aguas superficiales del Río Manzanares y su pluma.

Figure 7. Relation between the concentration $\left(\mu \mathrm{mol} \mathrm{L}^{-1}\right)$ of manganese in the three fractions extracted from the dissolved portion and the salinity in surface waters of the Manzanares River and its plume. 


\section{Manganeso}

El manganeso disuelto presentó un comportamiento no conservativo en la zona de estudio (fig. 7), con pocos aportes en el extremo fluvial, tanto en el período de sequía como en el de lluvia, con un aumento muy marcado en la zona de mezcla. La fracción prevaleciente durante el estudio fue la correspondiente al Mn asociado a D3, con un pequeño contenido de Mn asociado a D2 a salinidades intermedias en el período de lluvia y de Mn asociado a D1durante mayo. El contenido en la fracción D3 durante el período de lluvia osciló entre no detectado y $0.260 \mu \mathrm{mol} \mathrm{L^{-1 }}$ con las mayores concentraciones en septiembre, mientras que durante el período de sequía el mismo fluctuó entre no detectado y $1.027 \mu \mathrm{mol} \mathrm{L}^{-1}$ en mayo. Estos incrementos en las concentraciones pueden deberse a la desorción del Mn de la superficie del material particulado suspendido por del intercambio con los cationes $\mathrm{Na}^{+}$y $\mathrm{K}^{+}$ presentes en el agua de mar, ya que el Mn en el MES se encuentra principalmente adsorbido en la superficie de las partículas o como oxihidróxidos reactivos (Martínez y Senior 2001).

El manganeso es un elemento muy sensible a las condiciones redox y presenta una relativa movilidad en los ambientes marinos. El estado termodinámicamente estable del $\mathrm{Mn}$ en agua de mar oxigenada es el Mn (IV) insoluble. En condiciones reducidas se produce el ión Mn (II) soluble. La velocidad de oxidación de dicho metal es lenta; sin embargo, el Mn (II) inestable puede persistir por algún tiempo en aguas oxigenadas (Owens et al. 1997). Wollast et al. (1979), Hart y Davis (1981), Knox et al. (1981), Bewer y Yeats (1983), León (1995), León et al. (1997) y Márquez (1997) reportaron distribuciones no conservativas de este elemento, señalando que las pérdidas de manganeso pueden ocurrir por oxidación del Mn(II) a Mn(IV) con la formación de material en suspensión durante la mezcla estuarina.

Bender et al. (1977) reportaron un comportamiento opuesto en la Bahía de Narraganset y el Estuario St. Lawrence. Evans et al. (1977) observaron incrementos en el Mn disuelto a bajas salinidades y remociones a altas salinidades, lo que es compatibles con el incremento en la concentraciones de este elemento dentro de un rango de salinidades de 0.10 a 5.00 encontradas en el Estuario de Tamar (Morris et al. 1978). Estos autores señalaron que el comportamiento conservativo del manganeso disuelto fue debido a: (a) liberación del elemento desde los sedimentos del fondo y (b) desorción de las partículas en suspensión. Igualmente, manifestaron que el comportamiento no conservativo puede deberse a las pérdidas del metal por oxidación de los iones $\mathrm{Mn}(\mathrm{II})$ a $\mathrm{Mn}(\mathrm{IV})$ y enmascaramiento por iones hidróxidos o partículas orgánicas formadas durante la mezcla estuarina.

Wollast et al. (1979) indicaron que los máximos de Mn disuelto en los ríos Rin y Sheldt coincidían con los mínimos de $\mathrm{pH}$ y oxígeno disuelto, atribuyéndolo al incremento del desarrollo bacteriano que utiliza el dióxido de manganeso como through oxidation of $\mathrm{Mn}^{2+}$ to $\mathrm{Mn}^{4+}$ upon formation of suspended matter during estuarine mixing.

Antagonistic behaviors have been reported by Bender et al. (1977) at Narraganset Bay and the St. Lawrence Estuary. Evans et al. (1977) observed dissolved Mn increases at low salinities and Mn removals when salinity was high. These removals are compatible with Mn concentrations found in a salinity range of 0.1-5.0 psu at Tamar Estuary (Morris et al. 1978). These authors pointed out that the conservative behavior of dissolved Mn was prompted by the release of this element from the seafloor sediments and by desorption from the suspended particulate matter. Furthermore, they expressed the view that the nonconservative behavior may be ascribed to losses of the metal upon oxidation of $\mathrm{Mn}^{2+}$ to $\mathrm{Mn}^{4+}$ and to screening by the hydroxide ions or organic particles formed during estuarine mixing.

Wollast et al. (1979) indicated that dissolved Mn maxima in the Rhine and Sheldt rivers coincide with $\mathrm{pH}$ and dissolved oxygen minima, and attributed this coincidence to the bacterial increase that uses manganese dioxide as the ultimate electron acceptor during anaerobic respiration. Likewise, Knox et al. (1981) found that Mn maxima coincided with those of ammonium, and associated this phenomenon to desorption from the interstitial water in sediments.

\section{Nickel}

Figure 8 shows the Ni distribution in the dissolved fraction of the Manzanares River waters. This metal appeared only in the D3 fraction during the rainy season, in concentrations that fluctuated from below detection levels to $0.101 \mu \mathrm{mol} \mathrm{L}^{-1}$ in September, and from below detection to $0.039 \mu \mathrm{mol} \mathrm{L}^{-1}$ in November. Due to flocculation of the dissolved substances and metal uptake in the mixing zone, as a result of ion exchange at higher salinities and anthropogenic contributions, a nonconservative behavior with removal at low salinities was also observed in September. Free and hydrated Ni contributions were observed in the river front $\left(0.037 \mu \mathrm{mol} \mathrm{L}^{-1}\right.$ to undetected), which are quickly removed from the solution, possibly because of flocculation and biological processes.

By performing the metal-ammonium pirrolydin dithiocarbamate (APDC) formation technique, separating components with methyl-isobutyl-ketone (MIKB) and digesting them with acid and heat application, Márquez (1997) found a nonconservative behavior for the same zone, with removal at low salinities and dissolved $\mathrm{Ni}$ concentrations in a range between

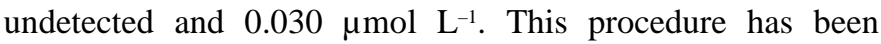
widely used for the extraction of heavy metals from seawater; however, the digestion of the sample can lead to metal loss by volatilization. Concentration of metals with Chelex-100 ion exchange resin is the technique most widely used in these cases (Landing et al. 1986, Lewis and Landing 1992, Yusof et al. 1994, Herrin et al. 2001, Jiann and Presley 2002, Özturk and Bizsel 2003, Alvarez et al. 2004). Applying the same metal 
último aceptor de electrones durante la respiración anaeróbica. De igual manera, Knox et al. (1981) encontraron que los máximos de Mn coincidían con los de amonio relacionándolo con la desorción a partir de las aguas intersticiales de los sedimentos.

\section{Níquel}

La figura 8 muestra la distribución del Níquel en la fracción disuelta de las aguas del Río Manzanares. Este metal se presentó únicamente en la fracción D3 durante el período de lluvia, en concentraciones que oscilaron entre no detectado y $0.101 \mu \mathrm{mol} \mathrm{L} \mathrm{L}^{-1}$ en septiembre y entre no detectado y $0.039 \mu \mathrm{mol} \mathrm{L}{ }^{-1}$ en noviembre. Igualmente se observa un comportamiento no conservativo con remoción a bajas salinidades en septiembre, debido a la floculación de las sustancias disueltas y adición del metal en la zona de mezcla, como resultado del intercambio iónico a salinidades más elevadas y los aportes debido a las actividades humanas que se desarrollan en la zona. En marzo se observaron aportes de Ni libre e hidratado en el

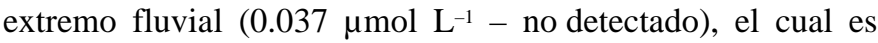
removido rápidamente de la solución, posiblemente debido a floculación y procesos biológicos.

Márquez (1997) encontró en este mismo ecosistema un comportamiento no conservativo con remoción a bajas salinidades con concentraciones del $\mathrm{Ni}$ disuelto total en un rango entre no detectado y $0.030 \mu \mathrm{mol} \mathrm{L} \mathrm{L}^{-1}$ utilizando la técnica de formación del complejo metal-amonio pirrolidin ditiocarbamato (APDC) y extracción con el solvente metil isobutil cetona (MIBK) seguidas por digestión con ácidos y calor. Este procedimiento fue ampliamente utilizado para la extracción de metales pesados del agua de mar. La digestión de la muestra puede conducir a la pérdida de metales por volatilización. Actualmente la técnica más ampliamente utilizada en estos casos es la concentración con la resina de intercambio iónico Chelex-100 (Alvarez et al. 2004, Özturk y Bizsel 2003, Jiann y Presley 2002, Herrin et al. 2001, Yusof et al. 1994, Lewis y Landing 1992, Landing et al. 1986). León (1995), aplicando la misma técnica para el estudio de los metales utilizada por Márquez (1997), obtuvo el mismo comportamiento para el Ni, observando concentraciones en el mismo rango reportado en este estudio, y deduciendo que el $\mathrm{Ni}$ disuelto es removido debido a los cambios en el $\mathrm{pH}$ y a la formación de los oxihidróxidos de Fe y $\mathrm{Mn}$. Al respecto, Moore y Ramammorthy (1984) señalan que las partículas coloidales de Fe y/o Mn cumplen un papel fundamental en la sedimentación del $\mathrm{Ni}$ en los ríos y ambientes estuarinos.

El comportamiento no conservativo del Ni también ha sido reportado por otros autores en diferentes regiones. Sharp et al. (1982) encontraron remoción de Ni debido a floculación a bajas salinidades en el estuario de Delaware (EUA). Windom et al. (1991) sugirieron que los máximos de Ni registrados en los estuarios de Medway (Canada) y Maeklong (Tailandia) durante el período de menor gasto del río, se debió a la regeneración a partir de la materia orgánica con liberación hacia la
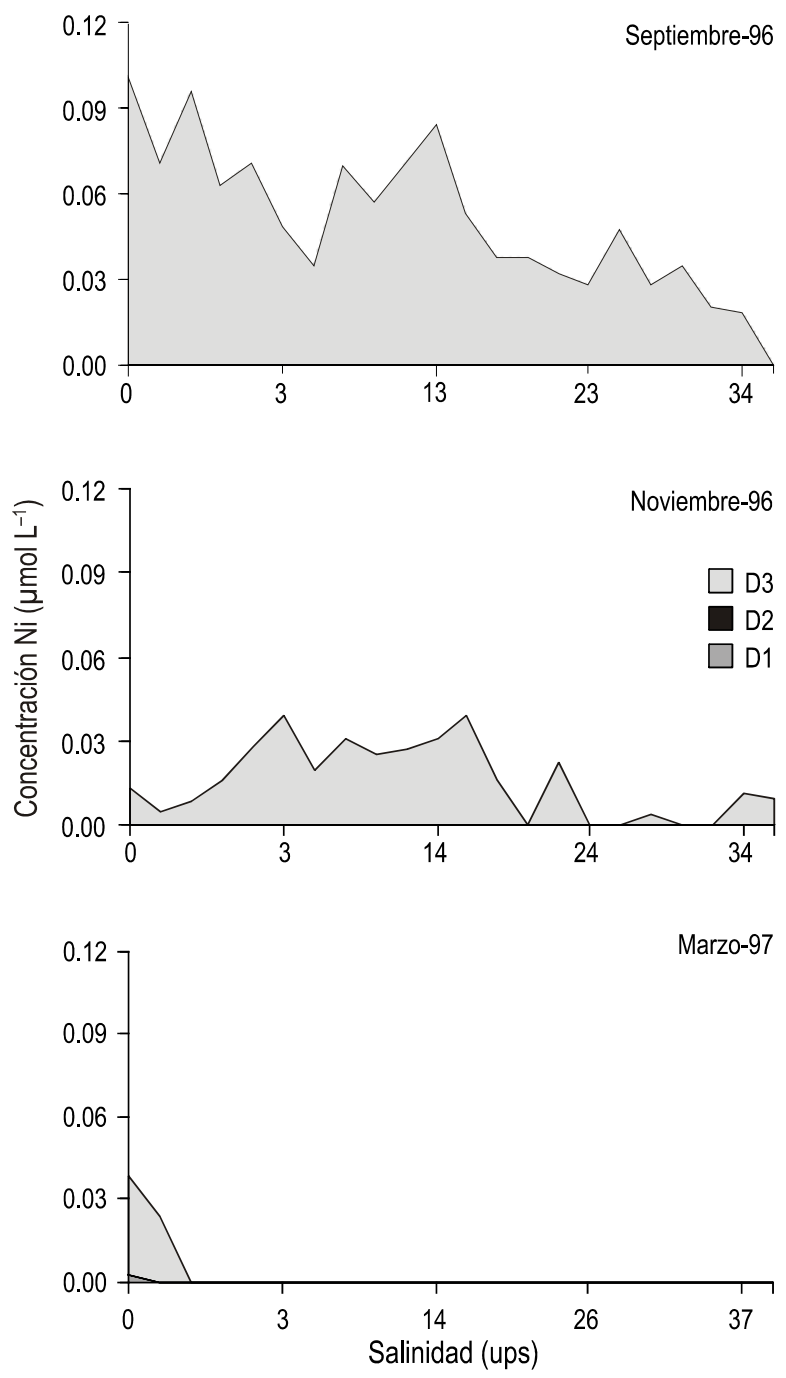

Figura 8. Relación entre la concentración $\left(\mu \mathrm{mol} \mathrm{L}^{-1}\right)$ de níquel en las tres fracciones extraídas de la porción disuelta y la salinidad en las aguas superficiales del Río Manzanares y su pluma.

Figure 8. Relation between the concentration $\left(\mu \mathrm{mol} \mathrm{L}^{-1}\right)$ of nickel in the three fractions extracted from the dissolved portion and the salinity in surface waters of the Manzanares River and its plume.

evaluation technique used by Márquez (1997), León (1995) observed the same behavior for $\mathrm{Ni}$, reporting concentration ranges similar to those found in this study, suggesting that the dissolved $\mathrm{Ni}$ is removed on account of changes in $\mathrm{pH}$ and formation of Fe an Mn oxyhydroxides. In regard to this, Moore and Ramammorthy (1984) have pointed out that Fe and/or Mn colloidal particles play a crucial role in $\mathrm{Ni}$ sedimentation of riverine and estuarine environments.

A nonconservative behavior of $\mathrm{Ni}$ has also been reported by other authors in different regions. Sharp et al. (1982) found Ni removal due to flocculation at low salinities in the Delaware Estuary (USA). Windom et al. (1991) suggested that the Ni maxima recorded in the Medway (Canada) and Maeklong (Thailand) estuaries during the period of lowest river outflow 
columna de agua, mientras que Apte et al. (1990) observaron un comportamiento no conservativo del $\mathrm{Ni}$ debido a la desorción a partir del sedimento en el rango de salinidades de 0-15 ups y disminución en sus concentraciones con el aumento de ésta. Esta tendencia también se observa en los diagramas del Ni disuelto en función del gradiente salino durante el período de lluvia para este estudio.

\section{Plomo}

En septiembre el plomo en su fracción disuelta se detectó únicamente en la fracción D3. El contenido de $\mathrm{Pb}$ para en este mes varía entre 0.010 y $0.021 \mu \mathrm{mol} \mathrm{L^{-1 }}$ en el extremo fluvial hasta las 3.25 ups, entre 0.010 y $0.017 \mu \mathrm{mol} \mathrm{L}^{-1}$ en el extremo marino y no se detectó en la región de mezcla (fig. 9). Esto refleja aportes de este metal desde el río y desde el mar como consecuencia de las actividades antropogénicas que se realizan en dicha región. En los demás meses de muestreo no se detectó plomo disuelto en las diferentes fracciones disueltas de las aguas del ecosistema en estudio, lo que puede estar reflejando que dicho metal está mayormente asociado al material en suspensión, ya sea adsorbido en las superficies de las partículas de arcillas o en oxihidróxidos de Fe y Mn. Márquez (1997) también encontró esta misma relación para el Pb del MES y el Fe y Mn del MES en el mismo río para 1995.

Los trabajos realizados por Malle (1990) y Morse et al. (1993) en la Bahía de Galveston, en los que se indica que el Pb estaba asociado al material en suspensión y a la fracción fina en suspensión en grandes proporciones, confirman las presentes observaciones. No obstante, Zhang (1995) reportó un comportamiento conservativo de este elemento en la fracción disuelta en los estuarios Changjiang y Huanche. ElbazPoulichet et al. (1996) ratificaron tal observación con los resultados encontrados en la pluma superficial del estuario del Río Rhône (Francia).

\section{Conclusiones}

Los flujos de metales pesados desde el Río Manzanares hacia la región costera bajo su influencia se incrementan durante el período de lluvia, lo que indica que dichos elementos están principalmente asociados al material en suspensión y en consecuencia con el gasto del río.

El proceso de remoción que experimentaron los metales pesados a bajas salinidades es debido a la floculación (principalmente formación de oxihidróxidos de $\mathrm{Fe}$ y $\mathrm{Mn}$ ) y rápida precipitación como consecuencia de los cambios en el pH y la fuerza iónica que tienen lugar durante la mezcla de los dos tipos de agua y que desestabilizan la solución de agua dulce.

Los metales pesados en la fracción disuelta presentan una composición en la que las mayores proporciones se encuentran asociadas a los ácidos húmicos (extraídos con la resina DEAE) y en forma libre e hidratada (extraídos con la resina HW, que son las más biodisponibles para los organismos vivos. were due to regeneration from the organic matter with release towards the water column, whereas Apte et al. (1990) observed a nonconservative behavior of $\mathrm{Ni}$ attributable to desorption from the sediment in salinities ranging from 0 to $15 \mathrm{psu}$, and a decrease in concentrations when salinity rose. This tendency is also reflected in the dissolved $\mathrm{Ni}$ diagrams plotted for this study in relation to the saline gradient during the rainy season.

Lead

In September, $\mathrm{Pb}$ in the dissolved phase was detected only in fraction $\mathrm{D} 3$. The $\mathrm{Pb}$ content for this month varied between 0.010 and $0.021 \mu \mathrm{mol} \mathrm{L}^{-1}$ in the fluvial front up to the $3.25 \mathrm{psu}$ gradient, between 0.010 and $0.017 \mu \mathrm{mol} \mathrm{L}^{-1}$ in the marine front, and was undetectable in the riverine-marine transition zone (fig. 9). This reflects contributions from both the river and the sea resulting from anthropogenic activities in the region. Dissolved $\mathrm{Pb}$ was not detected in the different dissolved fractions of the waters under study throughout the other sampling months, probably a reflection of the fact that this metal may be mainly bound to the suspended matter, either adsorbed to the surfaces of argillaceous particles or to Fe and Mn oxyhydroxides. Márquez (1997) also found a similar association for $\mathrm{Pb}, \mathrm{Fe}$, and $\mathrm{Mn}$ of the particulate matter in the same river in 1995.

The studies conducted by Malle (1990) and Morse et al. (1993) in Galveston Bay indicated that $\mathrm{Pb}$ was associated with the suspended matter and suspended fine fraction, confirming our observations. Nevertheless, Zhang (1995) reported a conservative behavior of $\mathrm{Pb}$ in the dissolved fraction of the Changjiang and Huanche estuaries, and Elbaz-Poulichet $e t$ al. (1996) confirmed this observation with the results obtained in the surface plume of the Rhone River estuary (France).

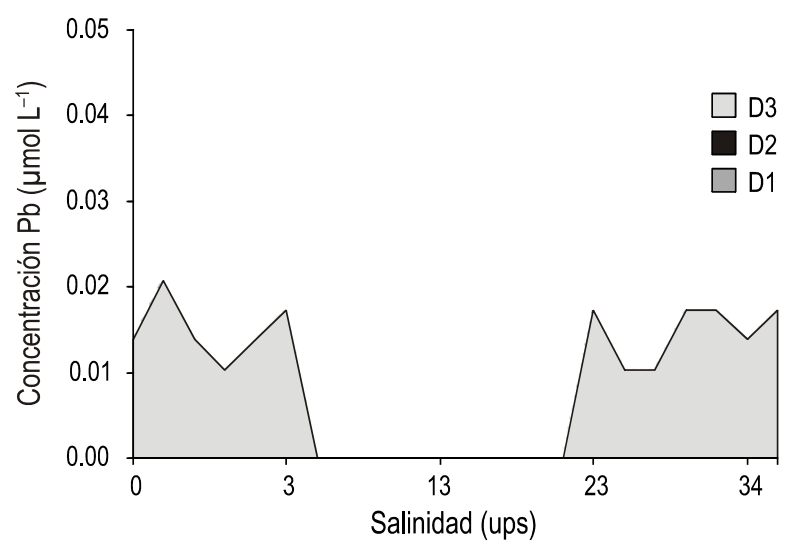

Figura 9. Relación entre la concentración $\left(\mu \mathrm{mol} \mathrm{L} \mathrm{L}^{-1}\right)$ de plomo en las tres fracciones extraídas de la porción disuelta y la salinidad en las aguas superficiales del Río Manzanares y su pluma.

Figure 9. Relation between the concentration $\left(\mu \mathrm{mol} \mathrm{L} \mathrm{L}^{-1}\right)$ of lead in the three fractions extracted from the dissolved portion and the salinity in surface waters of the Manzanares River and its plume. 


\section{Referencias}

Abdullah M, Boyle L. 1974. A study of the dissolved and particulate trace elements in the Bristol Channel. J. Mar. Biol. Assoc. UK. 54: 581-597.

Alvarez M, Malla M, Batistoni D. 2004. Performance evaluation of two chelating ion-exchange sorbents for the fractionation of labile and inert metals species from aquatic media. Anal. Bioanal. Chem. 378: 438-446.

Andreae MG. 1986. Chemical species in seawater and marine particulates. In: Berhard M, Brickman FE, Sadler PJ (eds.), The Importance of Chemical Speciation. Dahlem Konferenzen, Springer-Verlag, Berlin, pp. 301-335.

Apte S, Gadner M, Jun A, Ravenscroft J, Vale J. 1990. Trace metals in the Severn Estuary: A reappraisal. Mar. Pollut. Bull. 21: 393-396.

Aston S, Chester R. 1973. The influence of suspended particles on the precipitation of iron in natural waters. Estuar. Coast. Mar. Sci. 1: 225-231.

Bender M, Graham W, Klinhamer G. 1977. Manganese and iron in Narraganset Bay. Limnol. Oceanogr. 21: 665-683.

Bewer J, Yeats P. 1983. Behaviour of trace metal during estuarine mixing. River inputs to ocean system. United Nations, New York, pp. 103-115.

Comber SD, Gunn AM, Whalley C. 1995. Comparison of the partitioning of trace metals in the Humber and Mersey Estuaries. Mar. Pollut. Bull. 30: 851-860.

Coonley L, Baker E, Holland H. 1971. Iron in the Mullica River and in Great Bay, New Jersey. Chem. Geol. 7: 51-63.

Dassenakis M, Scollos M, Gaitis A. 1997. Trace metals transport and behaviour in the Mediterranean Estuary of Acheloos River. Mar. Pollut. Bull. 34: 103-111.

Duinker S, Nolting R. 1978. Mixing, removal and mobilization of trace metals in the Rhine Estuary. Neth. J. Sea Res. 12: 205-223.

Elbaz-Poulichet F, Garnier J, Guan DM, Martin JM, Thomas AJ. 1996. The conservative behaviour of trace metals $(\mathrm{Cd}, \mathrm{Cu}, \mathrm{Ni}$ and $\mathrm{Pb}$ ) and $\mathrm{As}$ in the surface plume of stratified estuaries: Example of the Rhone River (France). Estuar. Coast. Shelf Sci. 42: 289-310.

Evans D, Cutshall N, Ford A, Wolfe D. 1977. Manganese cycling in the Newport River estuary, North Carolina. Estuar. Coast. Mar. Sci. 5: 71-80.

Garnier JM, Guieu C. 2003. Release of cadmium in the Danube Estuary: Contribution of physical and chemical processes as determined by an experimental approach. Mar. Environ. Res. 55: 5-25.

Gibbs R. 1977. Transport phases of transition metals in the Amazon and Yukon rivers. Geol. Soc. Am. Bull. 88: 829-843.

Hahne H, Kroontje W. 1973. Significance of $\mathrm{pH}$ and chloride concentration in behavior of heavy metals pollutants: mercury (II), cadmium (II), zinc (II) and lead (II). J. Environ. Qual. 2: 444448.

Hart B, Davis S. 1981. Trace metals speciation in the freshwater and estuarine regions of Yarrah River (Victoria). Estuar. Coast. Shelf. Sci 12: 353-374.

Herrin R, Andren A, Armstrong D. 2001. Determination of silver speciation in natural waters. 1. Laboratory tests of Chelex-100 chelating resin as a competing ligand. Environ. Sci. Technol. 35: 1953-1958.

Holliday L, Liss L. 1976. The behavior of dissolved iron, manganese, and zinc in the Beaulieu Estuary, S. England. Estuar. Coast. Mar. Sci. 4: 349-353.

Huang W, Zhang W, Zhuo Z. 1992. Particulate element inventory in Huanghe: A large high-turbidity river. Geochim. Cosmochim. Acta 56: 3669-3680.

\section{Concluding remarks}

Our results show that the heavy metal flux from the Manzanares River towards the coastal region under its influence is increased during the rainy season, suggesting that these elements are mainly bound to the suspended matter and, thus, associated with the river outflow. The removal process experienced by heavy metals at low salinities is due to flocculation (especially the formation of Fe and Mn oxyhydroxides) and swift precipitation as a consequence of $\mathrm{pH}$ changes and the ion force ensuing during the confluence of the two bodies of water, which destabilizes the fresh-water solution. The heavy metals in the dissolved fraction present a composition whereby the largest proportions are either associated to humic acids (extracted with the DEAE resin) or in free and hydrated form (extracted with the HW resin), which are the species most readily bioavailable for living organisms.

Hurtado C. 1986. Comportamiento de algunos metales en sistemas estuarinos. Trabajo de grado (M.Sc.) en Ciencias Marinas, Instituto Oceanográfico de Venezuela, Universidad de Oriente, Cumaná, Venezuela, 300 pp.

Jiann K, Presley B. 2002. Preservation and determination of trace metal partitioning in river water by a two-column ion exchange method. Anal. Chem. 74: 4716-4724.

Knox S, Turner D, Dickson A, Liddicot M, Whitfield M, Butler M. 1981. Statistical analysis of estuarine profiles: Application to manganese and ammonium in the Tamar Estuary. Estuar. Coast. Mar. Sci. 13: 357-371.

Landing W, Haraldsson C, Paxeus N. 1986. Vinyl polymer agglomerate-based transition metal cation-chelating ion-exchange resin containing the 8-hydroxyquinoline funtional group. Anal. Chem. 58: 3031-3035.

León I. 1995. Distribución y comportamiento de los metales pesados (Fe, Mn, Ni, Cr, Cu, Cd, Pb y Zn) en la cuenca baja y pluma del río Manzanares, Cumaná, Venezuela, durante el periodo comprendido entre marzo y noviembre de 1994. Trabajo de grado (M.Sc.) en Ciencias Marinas, Instituto Oceanográfico de Venezuela, Universidad de Oriente, Venezuela, 214 pp.

León I, Senior W, Martínez G. 1997. Comportamiento del hierro, cromo, cadmio y plomo total en las aguas superficiales del río Manzanares, Venezuela, durante los períodos de sequía y lluvia en el año 1994. Caribb. J. Sci. 33:105-107.

Lewis BL, Landing WM. 1992. The investigation of dissolved and suspended-particulate trace metal fractionation in the Black Sea. Mar. Chem. 40: 105-141.

Magnusson B, Rasmussen L. 1982. Trace metal levels in coastal sea water. Mar. Pollut. Bull. 13: 81-84.

Malle KG. 1990. The pollution of the River Rhine with heavy metals. In: Heling D, Rothe P, Forstner U, Stoffers P (eds.), Sediment and Environmental Geochemistry. Springer-Verlag, Berlin, 279 pp.

Márquez A. 1997. Comportamiento y distribución de algunos metales pesados en fracciones disueltas y particuladas en aguas superficiales del Río Manzanares, Estado Sucre, Venezuela. Trabajo de grado, Licenciatura en Química, Escuela de Ciencias, Universidad de Oriente, Venezuela, $141 \mathrm{pp}$.

Márquez A, Senior W, Martínez G. 2000. Concentraciones y comportamiento de metales pesados en una zona estuarina de Venezuela. Interciencia 25: 284-291. 
Márquez A, Senior W, Martínez G, Castañeda J. 2002. Environmental conditions of the waters of the Manzanares River, Cumaná-Sucre, Venezuela. Bol. Inst. Oceanogr. Univ. Oriente 41: 15-24.

Martin J, Guan D, Elbaz-Poulichet F, Thomas A, Gordev V. 1993. Preliminary assessment of the distribution of some trace elements (As, $\mathrm{Cd}, \mathrm{Cu}, \mathrm{Fe}, \mathrm{Ni}, \mathrm{Pb}$ and $\mathrm{Zn}$ ) in a pristine aquatic environment in the Lena River estuary (Russia). Mar. Chem. 43: 185-199.

Martínez G, Senior W. 2001. Especiación de metales pesados (Cd, Zn, $\mathrm{Cu}$ y $\mathrm{Cr}$ ) en el material en suspensión de la pluma del Río Manzanares, Venezuela. Interciencia 26: 53-61.

Miles CJ, Tuschall JR, Brezonik PL. 1983. Isolation of aquatic humus with diethylaminoethylcellulose. Anal. Chem. 55: 410-411.

Moore J, Ramammorthy S. 1984. Heavy Metals in Natural Waters. Pergamon Press, UK, 268 pp.

Morris A, Mantoura R, Bale A, Holland K. 1978. Behaviour of some heavy metals in an estuarine zone. Nature 229: 303-327.

Morse J, Presley B, Taylor R, Benoit G, Santschi P. 1993. Trace metal chemistry of Galveston Bay: Water, sediments and biota. Mar. Environ. Res. 36: 1-37.

Okuda T, Fernández E, Bonilla J. 1978. Variación estacional del fósforo y nitrógeno inorgánico en el Golfo de Cariaco, Venezuela. Bol. Inst. Oceanogr. Univ. Oriente 17: 89-104.

Owens RE, Balls PW, Price NB. 1997. Physicochemical processes and their effects on the composition of suspended particulate material in estuaries: Implications for monitoring and modelling. Mar. Pollut. Bull. 34: 51-60.

Özturk M, Bizsel N. 2003. Iron speciation and biogeochemistry in different nearshore waters. Mar. Chem. 83: 145-156.

Palanques A. 1994. Distribution and heavy metal pollution of the suspended particulate matter on the Barcelona continental shelf (northwestern Mediterranean). Environ. Pollut. 85: 205-215.

Paulson AJ, Curl HC Jr, Cokelet ED. 1991. Remobilization of $\mathrm{Cu}$ from marine particulate organic matter and from sewage. Mar. Chem. 33: 41-60.

Sadiq M. 1992. Toxic Metals in Marine Environments. Marcel Dekker, New York, 389 pp.

Schneider P, Davey S. 1995. Sediment contaminants of the coast of Sydney, Australia: A model for their distribution. Mar. Pollut. Bull. 31: 262-272.
Senior W, Godoy G. 1990. Estudio físico-químico del río Manzanares, Cumaná-Venezuela. Bol. Inst. Oceanogr. Univ. Oriente 29: 160172.

Sharp J, Culberson C, Church T. 1982. The chemistry of the Delaware Estuary. General considerations. Limnol. Oceanogr. 27: 10151028.

Song Y, Müller G. 1995. Biogeochemical cycling of nutrients and trace metals in anoxic freshwater sediments of the Neckar River, Germany. Mar. Freshwater Res. 46: 237-243.

Stumm W, Morgan JJ. 1981. Aquatic Chemistry. Wiley, New York, $780 \mathrm{pp}$.

Thunell R, Varela R, Llano M, Collister J, Müller-Karger F, Bohrer R. 2000. Organic carbon flux in an anoxic water column: Sediment trap results from the Cariaco Basin. Limnol. Oceanogr 45: 300308.

Thurman EM. 1985. Organic geochemistry of natural water. Martinus Nijhoff/Dr. W. Junk Publishers, Dordrecht, pp. 338-340.

Tsunogai S, Uematsu M. 1978. Particulate manganese, iron and aluminum in coastal water, Funka Bay, Japan. Geochem. J. 12: 39-46.

Valette-Silver N. 1993. The use of sediment cores to reconstruct historical trends in contamination of estuarine and coastal sediments. Estuaries 16: 577-588.

Windom H, Byrd J, Smith R Jr, Hungspreugs M, Dharmvanij S, Thumtrakul W, Yeats P. 1991. Trace metal-nutrient relationships in estuaries. Mar. Chem. 32: 177-194.

Wollast R, Billen G, Duinker J. 1979. Behavior of manganese in the Rhine and Scheldt Estuaries. Physics and chemical behavior. Estuar. Coast. Mar. Sci. 8: 161-169.

Yeats P. 1993. Input of metals to the North Atlantic from two large Canadian estuaries. Mar. Chem. 43: 201-209.

Yusof A, Rahman N, Wood A. 1994. The accumulation and distribution of trace metals in some localized marine species. Biol. Trace. Elem. Res. 43-45: 239-249.

Zhang J. 1995. Geochemistry of trace metals from Chinese river/ estuary systems: An overview. Estuar. Coast. Shelf Sci. 41: 631658.

Zhang J, Huang W, Lin S, Liu M, Yu Q, Wang H. 1992. Transport of particulate heavy metal towards the China Sea: A preliminary study and comparison. Mar. Chem. 40: 61-178.

Recibido en noviembre de 2004; aceptado en marzo de 2006. 